\title{
A stress-based approach to the syntax of Hungarian focus ${ }^{1}$
}

\author{
KRISZTA SZENDRŐI
}

\begin{abstract}
A focused constituent contains the most prominent stress of the clause (Selkirk 1984, Reinhart 1995). Reinhart accounts for this by a PF/LF mapping rule. I extend this view to Hungarian, a language with contrastive focus movement, and show that a range of data, some of which pose a problem for a featuredriven approach, can be accounted for straightforwardly. Among these are the uniqueness of focus movement and the fact that verb-focusing does not strand the particle of particle-verbs (verb-movement generally strands it). The analysis extends to blocking effects between focusing and a phenomenon called particle climbing. It is concluded that the [+Focus]-feature is unnecessary to account for the data. Finally, it is shown that the alleged identificational focus vs. new information focus distinction of É.Kiss (1998b) is not supported by Hungarian data.
\end{abstract}

\section{Introduction}

I take a felicitous question-answer pair to indicate that the focus of the answer is the constituent that is questioned. So, (1b) has focus on the direct object in

1. This paper is the result of my $\mathrm{PhD}$ work at University College London. I am grateful to my former supervisors Ad Neeleman and Misi Bródy for their immense knowledge and their readiness to help. The stimulating atmosphere of the department also helped enormously in this work, nevertheless it is impossible to mention everybody here by name. For useful comments, thanks are also due to Peter Ackema, Hans van de Koot, Anikó Lipták, Tanya Reinhart, Neil Smith, Ildikó Tóth, and an anonymous reviewer. This work would not have been possible without the ORS Award of the British Government and further financial help from the Newby Trust and the Fox Memorial Trust. Their help is hereby acknowledged. 
the dialogue in (1), while the same utterance, with the same intonation, has VP focus in (2). (Caps indicate main stress; boldface marks focus.)

a. What did your friend buy?

b. My friend bought a BOOK.

a. What did your friend do?

b. My friend bought a BOOK.

(3) illustrates what is commonly known as the Hungarian contrastive focus construction (cf., e.g., Bródy 1990, 1995a). A constituent is fronted to a leftperipheral position in an answer to a $w h$-question and it receives contrastive focal interpretation. The focus in (1b) is often termed new information focus, while the one in (3b) is often called contrastive or identificational focus (e.g., É.Kiss 1998b; Zubizarreta 1998). (See Section 11 for more on this distinction.)
a. $\quad$ Mit
vett a barátod?
what-ACC bought the friend-yours
'What did your friend buy?'
b. (A barátom) egy KöNYVET vett. friend-my a book-ACC bought 'My friend bought a BOOK.'

However, note that (3) is in fact the closest possible translation of (1). In other words, (3b) is the most natural answer to (3a). Both (1) and (3) form a felicitous question-answer pair, so given our definition of focus, both involve a focus on the $\mathrm{DP}_{\mathrm{DO}}$. As Roberts (1998) already noted, both the focus in (1b) and the one in (3b) receive main stress (see the caps). It is in fact well-known that in many languages the focus of the sentence is marked by the main stress assigned to that sentence (Chomsky 1971; Dezsô 1974; Selkirk 1984; Harlig and Bardovi-Harlig 1988; Reinhart 1995; Neeleman and Reinhart 1998). In particular, Reinhart (1995: 62) argued that the focus of an utterance is any constituent containing the main stress of the utterance: the Stress-focus correspondence principle.

In this paper I show that the Stress-focus correspondence principle also holds for foci in Hungarian. I argue that in Hungarian the principle has direct consequences for the syntax of the language in the form of triggering phrasal movement. $^{2}$ This flies in the face of the well-known claim that phonology cannot influence syntax (Zwicky 1969; Zwicky and Pullum 1986; Vogel and Kenesei 1990; Miller et al. 1997). In this paper, I will question this claim as far as a

2. See Roberts (1998); Zubizarreta (1998); Büring (2001); Costa (to appear); Arregi (2001) and Büring and Gutiérrez-Bravo (2001), for similar approaches to focus in different languages. 
subset of phonological rules are concerned: the prosodic rules that apply at the clause-level (see Inkelas and Zec 1995 for essentially the same claim).

The paper is structured as follows. The first three preliminary sections contain the following: a short introduction to the relevant characteristics of Hungarian clause-structure; the standard analysis of the Hungarian FocusP due to Bródy (1990, 1995a); and the Hungarian stress rule. In Section 5, I claim that although Bródy's analysis is in itself correct, the motivation for it is wrong. Instead, I shall argue that the position known as [Spec, FP] is created in order to provide a position where the neutral, main stress rule assigns stress. In the case of 'focus movement' what really happens is movement of a constituent to the neutral stress position from a position that otherwise would not get stress. This is in order to satisfy the Stress-focus correspondence principle.

The rest of the paper describes different phenomena that receive a straightforward analysis under this stress-driven focus-movement approach. We obtain an explanation of the long-standing puzzle that FocusP is not recursive in Hungarian, although topic positions are. It is argued here that the second focus and any subsequent foci, but crucially not the first one, get stress by an extra, marked stress rule (Section 6). Section 7 is about verb focusing. In this construction a Particle-V complex does not strand its particle. This fact has been noted by Bródy (1990: 213), who described it using a syntactic filter. The present approach allows for a more insightful explanation. In Section 8, I shall argue that the same syntactic position, [Spec, FP], hosts particles (or other verbal modifiers) in the so-called particle climbing sentences. In this case, the opposite of focusing happens: the position is created to avoid stressing the otherwise clause initial verb. It follows that climbing and focusing should block each other, which is indeed the case. In Section 9 I show that the present approach accounts for cases of focus projection (cf. Selkirk 1984). Section 10 provides an analysis of the optionality of V-to-F movement in infinitivals with contrastive focus. Section 11 elaborates on the issue of new information vs. identificational focus in Hungarian proposed by É.Kiss (1998b).

The last section briefly discusses the theoretical implications of the paper. It is concluded that the [+Focus]-feature is unnecessary to account for the data presented here.

\section{Hungarian clause-structure}

Hungarian is famous for allowing great freedom in constituent order. In (4), it is shown that all the six logically possible word order variations for a threeword sentence are grammatical, however, not with the same meaning. Studies over the past twenty years have revealed that the Hungarian sentence is hierarchically structured. In particular, communication functions, such as topic or focus, are syntactically encoded. 

a. Józsi ismeri Marit.
Joseph knows Mary-ACC
b. Józsi Marit ismeri.
c. Marit Józsi ismeri.
d. Marit ismeri Józsi.
e. Ismeri Marit Józsi.
f. Ismeri Józsi Marit.
'Joseph knows Mary.'

The structure of the neutral sentence (i.e., one without a contrastive focus) for which I argue in this paper is in (5). Not all aspects of the phrase marker are addressed in the paper. For example, the inner structure of the VP is largely ignored. I assume, following É.Kiss (1994:19), that it is V-initial. ${ }^{3}$ I analyse topics such as a nó 'the woman' and a kalapját 'her hat' in (5) as VP-adjoined constituents. These bear phrasal stress if they are not accessible in the previous discourse, but never main stress. Topics do not have to be adjacent to the verb, and more than one of them can appear in one sentence in any order, see (5a) and (5b). Based on these observations I shall assume in what follows that they are adjoined to $\mathrm{VP}^{4}$.

(5)

a.

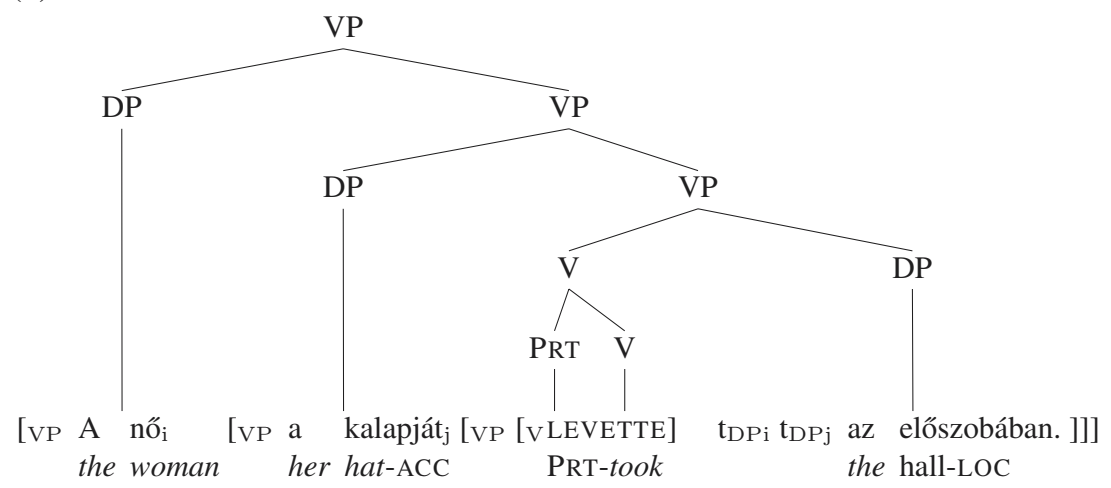

3. On the one hand, É.Kiss $(1992,1994)$ argues that Hungarian does not have a designated (i.e., specifier of a functional head) subject position. On the other hand, Marácz (1989) argues that there is a designated subject position, which follows the $\mathrm{V}$ at the spellout point. The analysis presented here is compatible with either view, as the crucial point here is that at the spellout point, in an unmarked utterance, the verb ends up in sentence-initial position, or is preceded by topics.

4. Note that I assume that the syntactic computation allows for the differentiation of specifiers and adjoined phrases. (See Neeleman and Van de Koot 2002 for a syntactic model that predicts the existence of adjunction.) 

b. [VP $A$ kalapját $\left[\begin{array}{llll}\mathrm{VP} & a & n o ̈ & {[\mathrm{VP}}\end{array}[\mathrm{v}\right.$ levette $]$ her hat-ACC the woman PRT-took
$\mathrm{t}_{\mathrm{DPi}} \mathrm{t}_{\mathrm{DPj}}$ az elöszobában.]]]
the hall-LOC

'The woman took her hat off in the hall.'

Sentences like the one in (5) contain particle-verbs. In Hungarian, there is a large class of verbal modifiers ${ }^{5}$ that form a lexical unit with the verb. They can modify the theta-grid or the c-selectional properties of the verb. Following Komlósy and Ackerman's (1983) and Komlósy's (1992) account, I take the Hungarian particle verb to form a complex verb (see also Neeleman's 1994 analysis for similar constructions in Dutch). The particle is assumed to be leftadjoined to the verbal head in syntax. Note that the PRT-V complex forms one word both morphologically and phonologically, with one stress falling on the PRT, as in Hungarian, stress at the word-level is leftward-oriented.

In (6) it is shown that even the same word order may correspond to different meanings, accompanied by different intonational patterns. (6a) makes a statement about Joseph, namely, that he knows Mary. (6b) means 'It is Joseph (and not Peter) that knows Mary'. It contains a contrastive focus. (6c) shows the structure I assume for (6b), which is discussed in the next section.

a. Józsi ISMERI Marit.

Joseph knows Mary-ACC

'Joseph knows Mary.'

b. JÓZSI ismeri Marit.

Joseph knows Mary-ACC

'It is Joseph who knows Mary.'

c.

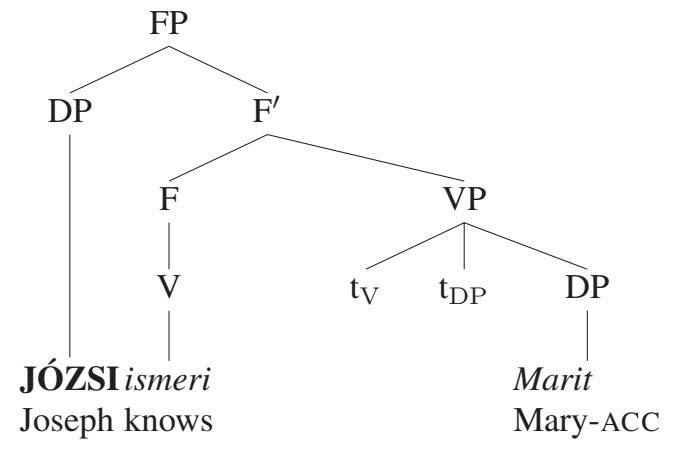

5. In this paper most of the examples contain particles, which form a subclass of verbal modifiers. All my claims hold for the other types, too. For a definition of verbal modifiers see Bródy (1990: 202). 


\section{$42 \quad$ Kriszta Szendröi}

\section{FocusP}

Bródy $(1990,1995 a)$ argues that in Hungarian a Focus phrase is projected on the left-periphery of the sentence. Contrastively focused constituents, arguments and adjuncts alike, move to [Spec, FP] in order to check their [+Focus]feature, where they receive contrastive interpretation. ${ }^{6}$ In a tensed sentence, this is accompanied by $\mathrm{V}$ movement to $\mathrm{F}$; thus the focused constituent and the verb are adjacent. The data supporting V-movement are sentences that contain verbal particles (PRT). In Hungarian the default position for a verbal particle is preverbal; it is immediately in front of the verb. In sentences which have a focused element, the particle follows the verb. This, Bródy (1990, 1995a) claims, is an indication of verb movement to F (cf. also Koster 1975): the particle is stranded by the movement of the verbal head of the complex predicate, as in (7). Topics adjoin to FP in this case. ${ }^{7}$

$$
\begin{aligned}
& \text { a. MARI hívta fel Pétert. } \\
& \text { Mary rang PRT Peter-ACC. } \\
& \text { b. *MARI fel hívta Pétert. } \\
& \text { Mary PRT rang Peter-ACC. } \\
& \text { 'MARY rang up Peter.' }
\end{aligned}
$$

In infinitival sentences Verb-raising seems to be optional. In these sentences, therefore, there is an empty functional head position by hypothesis. ${ }^{8}$

$$
\begin{array}{llll}
\text { a. Jobb lenne PÉTERT hívni fel. } \\
\text { better would-be Peter-ACC call-to PRT }
\end{array}
$$

6. For similar proposals in different languages see also: Rizzi (1997) on Italian, Tsimpli (1995) on Greek; Laka (1990), Ortiz de Urbina (1999) on Basque; Ouhalla (1994) on Arabic; Tuller (1992) on Chadic languages; Vilkuna (1995) on Finnish.

7. Note that universal quantifiers move between topics and the focus in Hungarian if they are to take wide scope. I do not discuss quantifiers here, as their movement is not triggered by a need to get stressed. They undergo QR. Since this movement is triggered at LF and not at PF, it falls outside the scope of this work.

An anonymous reviewer notes that the following pose a problem to the analysis presented here. The quantifier in (i) receives obligatory main stress and focus interpretation. This in itself is consistent with the Stress-focus correspondence principle. Nevertheless, the order of PRT and V shows that the verb following the quantifier is in situ. I leave the issue open for future research.

(i) MINDENKI eljött, nemcsak egy PÁRAN jöttek el. everybody PRT-came, not-only a few came PRT 'Not only a few people came, EVERYBODY came.'

8. I assume that this empty functional head lacks relevant features and has to lexicalise at some point in the derivation (Nash and Rouveret 1997). See Section 10 for discussion. 
b. Jobb lenne PÉTERT felhívni.

better would-be Peter-ACC PRT-call-to

'It would be better to ring up PETER.'

I accept Bródy's analysis as far as the syntactic positions of the constituents are concerned, but I argue against the claim that the motivation for focus movement is the presence of a syntactic [+Focus]-feature. Instead, I claim that the movement is triggered by stress.

\section{Hungarian prosody}

I follow the insight of Selkirk $(1984,1986)$ and Nespor and Vogel (1986) (contra Cinque 1993) that main stress is not assigned in the syntactic representation. Rather, each utterance has a prosodic structure alongside its syntactic structure and the two are related via mapping rules. Prosodic structure groups the linear string into phonological words $(\omega)$, which themselves form phonological phrases $(\phi)$, which in turn form an intonational phrase (IntP). The Nuclear Stress Rule (henceforth NSR) applies in the prosodic structure.

In particular, I propose that the syntax-phonology mapping on the domain of syntactic and phonological phrases is subject to the principle given in (9) (cf. Selkirk 1984, 1986; Nespor and Vogel 1986; Chen 1987; Inkelas 1989; Ghini 1993; McCarthy and Prince 1993; Neeleman and Weerman 1999; Truckenbrodt 1999; and to some extent Vogel and Kenesei 1987, 1990). The symmetric counterpart of the mapping rule, which refers to the right edge of the syntactic and prosodic domains, is operative in English and Italian, for instance.

Syntax-prosody mapping of phrases (Hungarian)

Align the left edge of a syntactic phrase with the left edge of a phonological phrase.

On the level of the clause and the intonational phrase, I suggested in Szendrói (2001) that the following four principles are operative in all three languages.

Syntax-prosody mapping of clauses (Hungarian, English and Italian)

a. Align all the left-edges of the largest extended projection of the verb with the left-edge of an intonational phrase.

b. Align all the left-edges of the intonational phrase with the leftedge of the largest extended projection of the verb.

c. Align all the right-edges of the largest extended projection of the verb with the right-edge of an intonational phrase.

d. Align all the right-edges of the intonational phrase with the rightedge of the largest extended projection of the verb. 


\section{$44 \quad$ Kriszta Szendröi}

It is well-known that in English and Italian main stress is assigned to the rightmost phonological phrase in the intonational phrase, and phrasal stress in these languages is assigned to the rightmost phonological word in the phonological phrase. In contrast, I follow Vogel and Kenesei $(1987,1990)$ and É.Kiss (1992: 93) in taking stress to be leftward-oriented in Hungarian. ${ }^{9}$ Thus, I argue that nuclear stress in Hungarian is assigned to the leftmost phonological phrase in the intonational phrase, while phrasal stress is assigned to the leftmost phonological word in the phonological phrase.

In the following diagrams I shall use a metrical tree notation (cf. Liberman 1975; Liberman and Prince 1977). Metrical trees are annotated with Strong (henceforth S) and Weak (henceforth W) labels. By assumption, S is assigned to the top node. The main stress falls on the node that is only dominated by S-s, which is indicated with bold in the diagrams. ${ }^{10} \mathrm{~A}$ formulation of the Hungarian nuclear stress rule in these terms is given in (11). (11a) spells out the rule on the phonological phrase level; (11b) on the intonational phrase level.

\section{Hungarian stress rule:}

a. Assign a Strong label to the leftmost phonological word in the phonological phrase. Assign Weak to the other phonological words.

b. Assign a Strong label to the leftmost phonological phrase in the intonational phrase. Assign Weak to the other phonological phrases.

c. Assign a Strong label to the intonational phrase.

Let me start by illustrating the application of the syntax-prosody mapping principles together with the stress assignment rules on the DP. As shown in (12), in a modified DP stress falls on Spec of NP (cf. Vogel and Kenesei 1990: 360-361). The Hungarian determiner forms a single phonological word with material that follows. In other words, it phonologically cliticises onto the following phonological word in Hungarian. This is a cross-linguistically common property of functional elements (cf., e.g., Zubizarreta 1998 for Romance).

9. Kálmán et al. (1989) and Kálmán and Nádasdy (1994) present a different approach to Hungarian stress, which is discussed in Section 11.

10. Note that secondary (clausal) stress falls on the node(s) that is (are) Weak on the phonological phrase level, but Strong otherwise. In this paper, I largely ignore the presence of secondary stress as it does not bear directly on the issue of focus. See Section 11 and Szendrői (2001) for some discussion. 
(12)

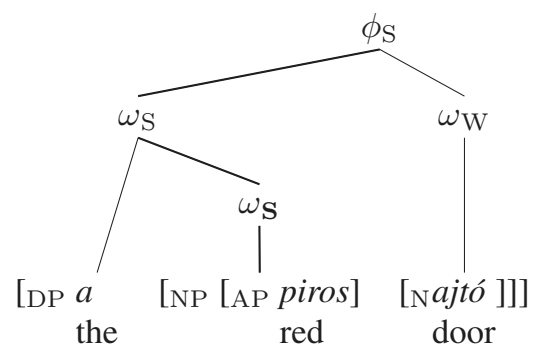

As (13) illustrates, if the specifier of the DP itself is filled, the DP corresponds to two phonological phrases with two phrasal stresses, one falling on [Spec, $\mathrm{DP}]$ the other on [Spec, NP]. ${ }^{11}$

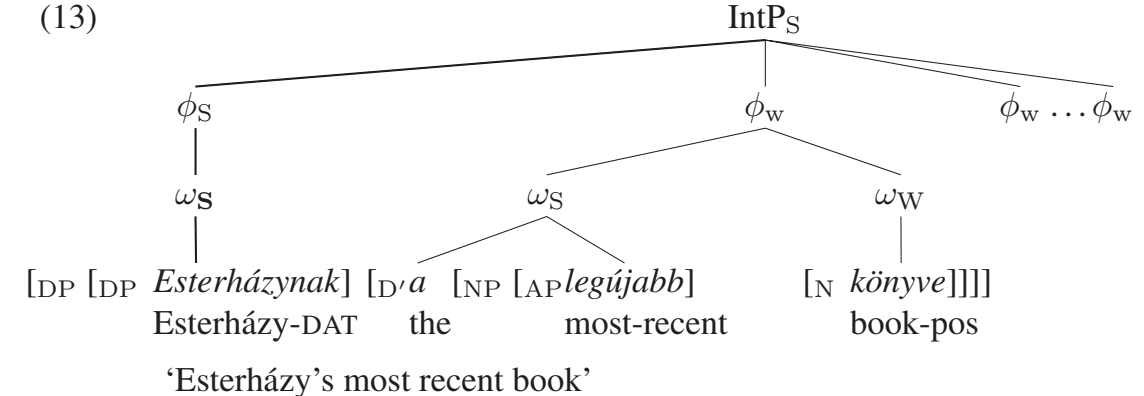

As I assumed in Section 2, in the unmarked case, the Hungarian clause corresponds to a VP. According to the clausal mapping principles in (10), every left and right edge of the VP is aligned with a left and right edge of an intonational phrase. So, in case of left-adjunction to VP, the leftward brackets of both VPsegments are mapped onto leftward IntP-brackets, as illustrated in (14). Given that the phrasal mapping principle in (9) is sensitive to the left-hand brackets of each syntactic phrase, the left edge of the subject DP, the left edge of the lower segment of the VP and the left edge of the object DP correspond to the left edges of three phonological phrases (cf. 14).

11. Note that the Obligatory Contour Principle, which prohibits immediately adjacent stresses, does not seem to be observed in Hungarian. 
(14)

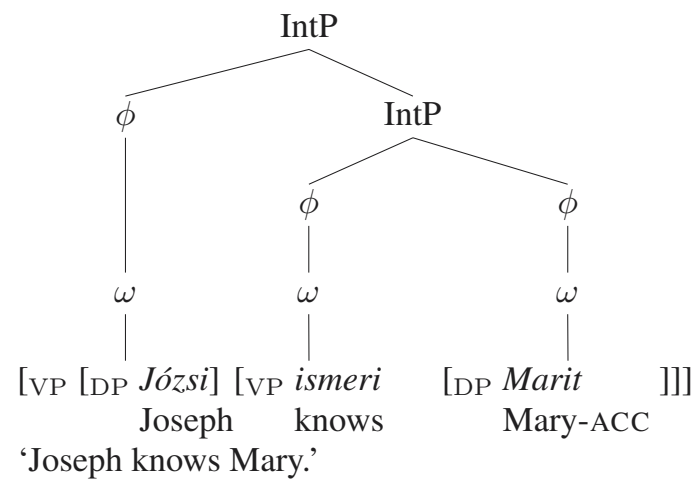

Following Truckenbrodt's (1999) proposal for German, I assume that the stress rule in Hungarian (cf. 11) operates in a way that phonologically adjoined material is treated as extrametrical in the sense that it is skipped by the stress rule. ${ }^{12}$ In effect, in (15) it is the lower segment of the intonational phrase that is the domain of the stress rule. Given these assumptions, topics, which were earlier on argued to be adjoined to VP in the syntactic representation of the unmarked utterance, will be in an adjoined position on the intonational phrase level. This correctly derives that topics in Hungarian bear phrasal stress, if they are not accessibly discourse-linked in Ariel's (1990) sense, but never take the main stress of the clause. Rather, given the phrasal and clausal stress rules in (11), in the unmarked Hungarian utterance, main stress falls on the verb. See (15) (cf. 5).

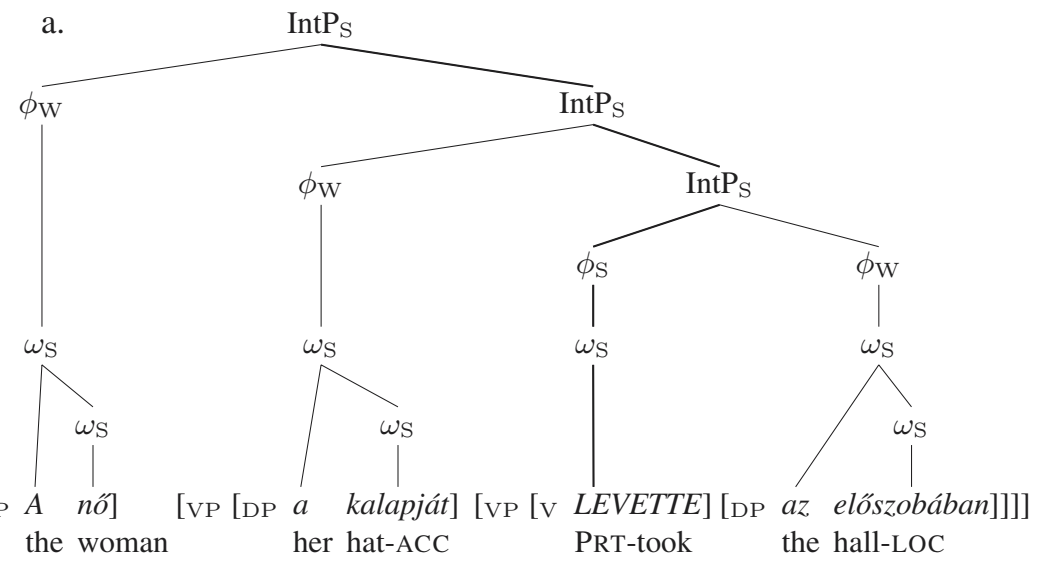

12. See Szendrői (2001) for an analysis that derives this from independently necessary assumptions. 
b. [VP [DP A kalapját] [VP [DP $a$ nó] [VP [V LEVETTE] [DP $a z$ elôszobában.]]]]

'The woman took her hat off in the hall.'

\section{Stress-driven focus movement}

As shown in (15), main stress falls on the verb (or on its particle) in a neutral Hungarian sentence. Following Reinhart (1995: 62), I make the following assumption.

Stress-focus correspondence principle:

The focus of a clause is a(ny) constituent containing the main stress of the intonational phrase, as determined by the stress rule.

In English, nuclear stress falls on the object in a transitive construction. Neeleman and Reinhart (1998) showed that if a constituent other than the object is to be focused, this constituent gets stress by a special prosodic rule, stress strengthening, in order to satisfy (16). The main claim of this paper is that, in Hungarian, the Reinhartian requirement on focus can be satisfied by movement of the focused constituent to a left-peripheral position.

Stress-driven movement:

In Hungarian, movement of the focused constituent to the left-periphery is triggered by (16), the requirement that a focused constituent be stressed.

In a non-neutral sentence, the main stress falls on the focused constituent, as it is the leftmost element in the clause (cf. 11). The [Spec, FP] position hosts the focused constituent. Topics adjoin to FP in this case. Note that in the present proposal $\mathrm{F}$ stands for Functional head rather than Focus head. The structure is given in (18). 
(18)

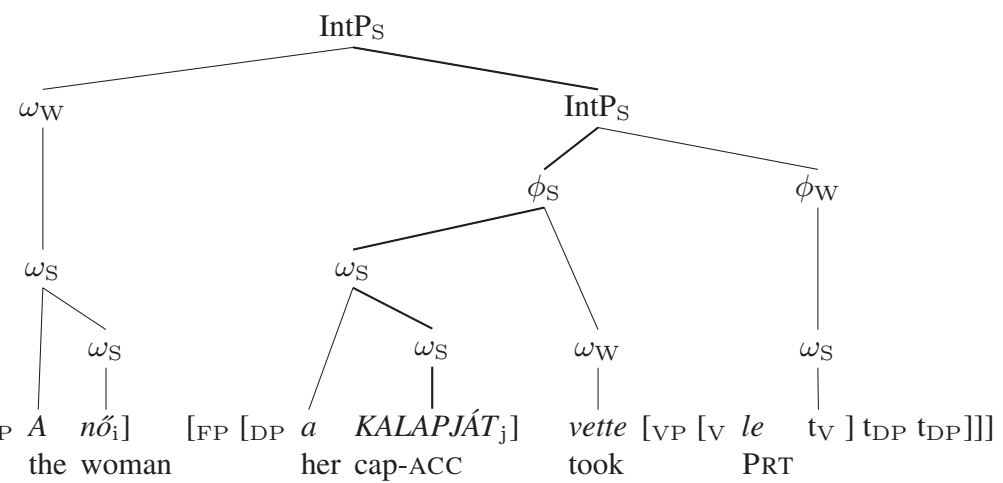

'It was her hat that the woman took off (not her scarf).'

Let me spell out some immediate consequences of this approach. In the standard minimalist feature-based treatment of the Hungarian focus construction, the movement of the focused constituent is motivated by the need to check the [+Focus]-feature. Three questions come to mind. First, as the [+Focus]feature is only interpreted at LF, why does the movement of the focused constituent happen overtly? Second, why is this movement accompanied by the movement of $\mathrm{V}$ to $\mathrm{F}$ at least in a tensed clause? And third, why does the focused constituent move to the left-peripheral position? A feature-based analysis gives the following, partial answers to these questions. The [+Focus]-feature is strong in Hungarian, hence the overt movement of the focused constituent. So is the V-feature of (a tensed) F, hence V-to-F. The movement is to the leftperiphery, in order to allow the focused constituent to take scope. These answers are unsatisfactory in several respects. Both the movement of the focused constituent and the verb could be covert and the same interpretation would be derived at LF. The focused constituent could take scope by appearing on the right-periphery, too. Arguably, this possibility is allowed for postverbal universal quantifiers in Hungarian. Whatever the analysis of these turns out to be, movement to the right or movement to the left and remnant movement of the clause above, the question arises why this option is not available for foci.

A stress-based analysis, on the other hand, seems to shed more light on these issues. In order to satisfy (16), the focused constituent needs to get stress. Therefore it moves to the left-periphery, as stress is assigned to the leftmost constituent of the clause in Hungarian. Given that the focused phrase moves to pick up main stress, it cannot move to an adjoined position, since adjoined phrases are 'skipped' by the stress rule (cf. 11). The movement of the verb is necessary to license the functional head position (see Section 10 for further discussion). Finally, as the movement of the focused constituent is driven by stress, it evidently cannot be postponed until the covert syntax. 
Note that the prosodic operation of stress strengthening (cf. Neeleman and Reinhart 1998) and the stress-driven movement operation proposed here do not occur freely. Rather, they are subject to economy, as in (19).

Economy violation:

Take fully derived (syntactically and prosodically) structures $\mathrm{D}_{\mathrm{i}}$ and their interpretations $\mathrm{I}_{\mathrm{i}}$ as ordered pairs. $\left\langle\mathrm{D}_{1}, \mathrm{I}_{1}\right\rangle$ is ruled out as an economy violation if and only if there exists $\left\langle\mathrm{D}_{2}, \mathrm{I}_{1}\right\rangle$, and $\mathrm{D}_{2}$ involves less operations (syntactic or prosodic) than $\mathrm{D}_{1}$.

(Following Reinhart, 1995: 48 and Fox 1994)

Thus, stress strengthening in English and stress-driven movement in Hungarian only apply if they derive an interpretation that was otherwise unavailable. (See Section 9 and Szendrói 2001 for more discussion of the relation between focus and economy.)

\section{Uniqueness of the syntactic focus position}

As there is only one main stress in a clause, one might think that only one focused constituent can be present in a clause in languages that have a specific syntactic focus position. As it turns out, this conclusion is much too strong. As the following example illustrates, there are in fact cases where pragmatically there are two contrastively focused constituents in a sentence:

$$
\begin{aligned}
& \text { CSAK KÉT LÁNY választott CSAK EGY KÖNYVET. } \\
& \text { only two girls chose only one book-ACC } \\
& \text { 'It was only two girls who chose only one book.' } \\
& \text { *'It was only one book that only two girls chose.' (É.Kiss 1998a: 16) }
\end{aligned}
$$

Bródy (1990) argues that in this case the second constituent is an operator in situ. É.Kiss (1998a) argues that this cannot be right, as the sentence is not ambiguous between the two readings where one focused constituent takes scope over the other. If this case was comparable to $w h$ in situ in English one would expect ambiguity. She proposes that FocusP is recursive in Hungarian, and that the verb moves to the higher Focus head via the lower one. The following examples cast some doubt on her reasoning.
a. CSAK HÁRMAN ettek meg CSAK KÉT KENYERET. Only three ate PRT only two bread-ACC
b. *CSAK HÁRMAN ettek CSAK KÉT KENYERET meg. Only three ate only two bread-ACC PRT 'It was only three people who ate up only two slices of bread.' 
Following Bródy (1990) I assume that a diagnostic property of verb movement in Hungarian is that the particle of a particle verb has to be stranded in the VP. If in (21b) CSAK KÉT KENYERET 'two slices of bread' was indeed a lower [Spec, FP], particles should never precede it. Particles are independently ruled out from a topic position, because they are not referential.

É.Kiss (1998a) suggests that the ungrammaticality of (21b) is due to the fact that the PRT is phonologically too light and has a tendency to cliticise onto the verb. This may be so, nevertheless this must be a phonological phenomenon and not as she argues the syntactic incorporation of the PRT into the V from the right, following an excorporation from the complex predicate and subsequent movement to $\mathrm{F}$. Excorporation of the non-head of a complex predicate is not allowed (Ackema 1995; Bródy 1997; contra Roberts 1991), so the particle cannot move out of the complex verb by head-movement. ${ }^{13}$

Another possibility would be to assume that the whole complex moves and the particle is stranded in an intermediate position, while $\mathrm{V}$ moves on to the highest F. But, stranding in intermediate positions is not otherwise allowed, as a moved element is an island (cf. Ross 1967, Wexler and Culicover 1980). This is illustrated in (22).

\section{(22) *Who do you think [friends of $\left.\mathrm{t}_{\mathrm{j}}\right]_{\mathrm{i}}$ John likes $\mathrm{t}_{\mathrm{i}}$ ?}

Thus, on the basis of (21a) and (21b), I assume that only one focused constituent may undergo overt focus movement in Hungarian; the second one remains in situ until the spellout point and gets focal stress via a last resort, extra stress rule. ${ }^{14}$

Thus it follows that Hungarian has a unique syntactic 'focus'-position, because it has a unique position for main stress. Topics and quantifiers do not seem to have a PF-requirement to get stressed (except for the case mentioned in Footnote 7), so it is not surprising that they appear recursively in the leftperiphery. The second focus (and any subsequent foci) do not move, at least

13. It may undergo phrasal movement (see Bródy 1997; and Section 8).

14. As expected, in a language, such as Italian, where stress is right-peripheral, the focused element moves to the right-periphery of the clause (Samek-Lodovici 1996). For instance, in an answer to a wh-question in (ia), the $\mathrm{DP}_{D O}$, Gianni 'John', appears in the non-canonical right-peripheral position (ib) and picks up the unmarked right-peripheral main stress.

(i) a. A: Chi non hai presentato a nessuno?

who not have-you introduced to nobody

'Who did you not introduce to anybody?'

b. B: Non ho presentato $\mathrm{t}_{\mathrm{i}}$ a nessuno GIANNI .

not have-I introduced to nobody Gianni

'I haven't introduced to anybody JOHN.'

For reasons of space, a more lengthy discussion of Italian has to be omitted here, but see Szendrői (2002). 
not triggered by PF, as the main stress position is already occupied by the first focus. The second focus and any subsequent foci get stress and focus interpretation by an extra phonological operation whether they move or not. Therefore they stay in situ, unless LF requires otherwise.

Recall that É.Kiss (1998a) argued that the view that is advocated here, which takes the second and subsequent foci to be in situ (at least until spellout), cannot be right as the scopal order of multiple foci rigidly follows their surface order. But this observation does not necessarily entail that all foci have moved to an A-bar position overtly. In fact, under the particular definition of economy (19) utilised here, it can be shown that in a sentence, such as (21a), which involves two foci, only the first one moves.

Let us assume that the intended interpretation, $\mathrm{I}_{1}$, is that $\mathrm{F}_{1}$, the first focus, CSAK HÁRMAN 'only three people', takes scope over $\mathrm{F}_{2}$, the second one, CSAK KÉT KENYERET 'only two slices of bread'. One may derive $\mathrm{I}_{1}$ with the following derivation, which I shall call $\mathrm{D}_{1}$, see (23a). $\mathrm{F}_{1}$ moves overtly to the main stress position, and thus will acquire focus interpretation at the conceptual-intentional interface by the stress-focus correspondence principle. $\mathrm{F}_{2}$ remains in situ and acquires stress and thus focus interpretation by an extra phonological operation. Since $\mathrm{F}_{1}$ asymmetrically c-commands $\mathrm{F}_{2}$, it takes scope over it. Of course, $\mathrm{F}_{2}$ may in principle undergo $\mathrm{QR}$ targeting a position above $\mathrm{F}_{1}$, taking scope over it, thus not deriving $\mathrm{I}_{1}$ any more. But the derivation where $F_{2}$ undergoes $Q R$ is not $D_{1}$ but as the reader will shortly see, $D_{3}$. To sum up so far, the intended interpretation, $\mathrm{I}_{1}$, is derived by the derivation $\mathrm{D}_{1}$.

$$
\begin{array}{ccc}
\mathrm{F}_{1}: \begin{array}{l}
\text { CSAK HÁRMAN } \\
\text { 'only three people' }
\end{array} & \mathrm{F}_{2}: & \begin{array}{l}
\text { CSAK KÉT KENYERET } \\
\text { 'only two slices of bread' }
\end{array} \\
\mathrm{I}_{1}: \mathrm{F}_{1}>>\mathrm{F}_{2} & \mathrm{I}_{2}: \mathrm{F}_{2}>>\mathrm{F}_{1}
\end{array}
$$

a. $\left\langle D_{1}, I_{1}\right\rangle: F_{1}$ moves overtly, $F_{2}$ stays in situ.

Now let us try to derive the interpretation, $\mathrm{I}_{2}$, where $\mathrm{F}_{2}, \boldsymbol{C S A K} \boldsymbol{K} \boldsymbol{E} \boldsymbol{T}$ KENYERET 'only two slices of bread', takes scope over $\mathrm{F}_{1}, \boldsymbol{C S A K} \boldsymbol{H A} \boldsymbol{A} \boldsymbol{R A N}$ 'only three people'. One straightforward way is what I shall call $\mathrm{D}_{2}$, which goes as follows. $\mathrm{F}_{2}$ moves to the left-periphery where it takes main stress and thus focus interpretation. $\mathrm{I}_{2}$ is derived by simply leaving $\mathrm{F}_{1}$ in situ. See (23b). Another possible derivation of $I_{2}$, which I shall call $D_{3}$, is to take $D_{1}$ as described above and $\mathrm{QR} \mathrm{F}_{2}$ at $\mathrm{LF}$ to a position where it takes scope over $\mathrm{F}_{1}$. See (23c).

$$
\begin{aligned}
& \mathrm{F}_{1} \text { : CSAK HÁRMAN } \mathrm{F}_{2} \text { : CSAK KÉT KENYERET } \\
& \text { 'only three people' 'only two slices of bread' } \\
& \mathrm{I}_{1}: \mathrm{F}_{1}>>\mathrm{F}_{2} \quad \mathrm{I}_{2}: \mathrm{F}_{2}>>\mathrm{F}_{1}
\end{aligned}
$$


$\left\langle D_{3}, I_{2}\right\rangle$ is ruled out by the existence of $\left\langle D_{2}, I_{2}\right\rangle$.

However, this derivation is ruled out by our definition of economy (19). This is so because, $\left\langle\mathrm{D}_{3}, \mathrm{I}_{2}\right\rangle$ contains two instances of movement, while $\left\langle\mathrm{D}_{2}, \mathrm{I}_{2}\right\rangle$ only one instance. Similarly, overt movement of $F_{2}$ and subsequent raising of $F_{1}$ over it at LF, which I shall call $\mathrm{D}_{4}$, will be equally ruled out by the availability of the derivation, $\mathrm{D}_{1}$, where the first focus moved overtly and the second one remained in situ. Compare (23d) with (23a).

$$
\begin{aligned}
& \mathrm{F}_{1} \text { : CSAK HÁRMAN } \mathrm{F}_{2} \text { : CSAK KÉT KENYERET } \\
& \text { 'only three people' 'only two slices of bread' } \\
& \mathrm{I}_{1}: \mathrm{F}_{1}>>\mathrm{F}_{2} \quad \mathrm{I}_{2}: \mathrm{F}_{2}>>\mathrm{F}_{1}
\end{aligned}
$$

d. $\left\langle\mathrm{D}_{4}, \mathrm{I}_{1}\right\rangle: \mathrm{F}_{2}$ moves overtly, $\mathrm{F}_{1}$ moves to a position above $\mathrm{F}_{2}$ at LF.

$\left\langle D_{4}, I_{1}\right\rangle$ is ruled out by the existence of $\left\langle D_{1}, I_{1}\right\rangle$.

It also follows that under the original interpretation, $\mathrm{I}_{1}$, the second focus, $\mathrm{F}_{2}$, cannot move to an A-bar position c-commanded by $\mathrm{F}_{1}$, which I shall call $\mathrm{D}_{5}$. See (23e). This is so, because there exists a derivation, $D_{1}$, which arrives at the same interpretation, $\mathrm{I}_{1}$, and which contains one less instance of movement.

$$
\begin{aligned}
& \mathrm{F}_{1} \text { : CSAK HÁRMAN } \quad \mathrm{F}_{2} \text { ： CSAK KÉT KENYERET } \\
& \text { 'only three people' 'only two slices of bread' } \\
& \mathrm{I}_{1}: \mathrm{F}_{1}>>\mathrm{F}_{2} \quad \mathrm{I}_{2}: \mathrm{F}_{2}>>\mathrm{F}_{1}
\end{aligned}
$$

To conclude, the rigid scopal relation of the two foci in an example like (21a) do not entail that both foci must sit in A-bar positions. To the contrary, under the definition of economy adopted here, (19), it follows that scopal disambiguation between two elements involves one instance of movement. Similarly, in a sentence with two foci and a universal quantifier, which takes lowest scope, both foci move, as disambiguation of scope between three elements necessitates two instances of movement. But crucially, in this latter case the movement of the second focus is triggered at LF, and not at PF. It is essentially a QR operation.

\section{Verb focusing: no particle stranding}

Recall the claim about Hungarian clause-structure that, just like in V2 in the Germanic and Scandinavian languages, the $\mathrm{V}$ leaves its particle stranded in the VP in the case of V-to-F movement accompanying the movement of a focused 
constituent to [Spec, FP]. Interestingly enough, if the verb itself is focused or the proposition is asserted, the neutral PRT-V order is not disturbed. As (24) illustrates, the particle appears in front of the verb. ${ }^{15}$
a. De, [vp én [vp ODAVITTEM a levelet]].
But I PRT-took the letter-ACC
'But, I TOOK the letter THERE, (not brought it here.)'
b. De, [vp én [vp ODAVITTEM a levelet]].
But I PRT-took the letter-ACC
'But, I DID take the letter there.'

Under the present proposal, this is easily accounted for. The verb is in the position where main stress is assigned, so there is no need for it to move, therefore it stays in situ and the PRT-V order is preserved.

This phenomenon has been captured by a kind of 'doubly-filled COMPfilter' by Bródy (1990: 212). Bródy (1990) argued that if [Spec, FP] is filled, the strong $\mathrm{V}$ feature of the Focus-head only attracts the bare V, in a similar way to V2 languages such as Dutch (cf. Koster 1975). However, if the verbal complex is attracted to the Focus-head by the presence of a $[+\mathrm{F}]$, then the whole complex moves.

\section{Doubly-filled Focus filter}

Either the F head contains a complex head, or [Spec, FP] is overtly filled, but not both. (cf. Bródy 1990)

This reasoning has the shortcoming that it assumes that under verb focusing, the verbal complex undergoes head-movement as a whole, without stranding the particle. This is not attested in any other construction in Hungarian, or in any of the V2 languages. In these languages, if $\mathrm{V}$ moves to $\mathrm{C}$, the particle is stranded.

I argued above that the movement of the focused constituent is triggered by the need to get main stress, rather than by the presence of a syntactic [+Focus]feature. If so, this phenomenon receives a straightforward explanation. In (24) stress falls on the complex verb by the stress rule (cf. 11). This is so, as the verbal complex is the leftmost constituent in the clause. So the focused verbal

15. The V-PRT order is marginally possible for some speakers, but even speakers who allow it only accept it if the simplex verbal head itself is contrasted, see (i). In (i), stress falls on the verbal head. The verb moves to $\mathrm{F}$ to get stress by the stress rule, (11), and contrastive interpretation, hence the reading that contrasts the simplex, verbal head.

(i) ?Péter SZALADT ki, nem MENT ki.

Peter ran PRT not walked PRT

'Peter didn't walk out, he RAN out.' 


\section{$54 \quad$ Kriszta Szendröi}

complex stays in situ, because it is already in the main stress position. There is no trigger for its movement, therefore, the PRT-V order is not disturbed.

To conclude, the undisturbed PRT-V order attested in verb focusing suggests that the verbal complex is in situ. This follows from the assumptions made earlier that the Hungarian VP is V-initial, Hungarian stress is leftward oriented, and that focus-movement is not feature-driven, but triggered by the need of the focused phrase to get main stress.

\section{Particle climbing}

So far I have shown that the position known as [Spec, FP] is not there to provide contrastive focal interpretation, but it is licensed by the movement of $\mathrm{V}$ to provide a position where a constituent that otherwise would be unstressed can get the main stress of the intonational phrase. It is only by Reinhart's (1995) generalization in (16) that the link between stress and focus is established. I proceed to show that the same position can also be created for the opposite reason: to avoid stressing of a constituent that would otherwise be clause-initial. Note that this kind of stress-avoiding operation can only apply to verbs, given the leftward orientation of the Hungarian stress rule and the V-initial nature of the unmarked clause.

In Hungarian, there are several classes of infinitival complement taking verbs. One class involves the so-called climbing verbs. A characteristic of climbing verbs, noted by Komlósy (1992), is that they cannot bear phonetically neutral sentential stress. They can only take main stress if contrastively or emphatically focused, see (26). Here they bear contrastive stress. In fact, these verbs behave as if they were functional heads (or 'semi-lexical' as in Van Riemsdijk 1998). As I claimed in Section 4, functional heads do not take neutral stress. However, they do allow contrastive stressing and contrastive interpretation, even if it needs some contextualising, see (27).

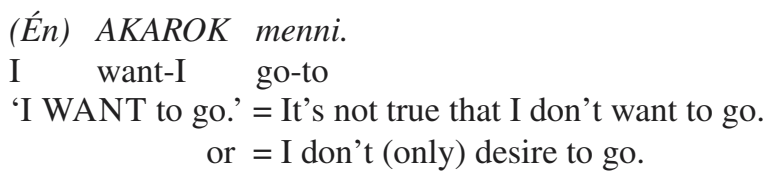

$$
\begin{aligned}
& \text { Ez nem EGY ut Budapestre. Ez AZ út Budapestre. } \\
& \text { this not a road Budapest-to this the road Budapest-to } \\
& \text { 'This not A road to Budapest. This is THE road (to Budapest).' }
\end{aligned}
$$

Note that the fact that climbing verbs may get stress in marked cases suggests that they are similar to pronouns in English. As (28a) and (28b) show, English pronouns are not stressed in the unmarked case, but may get stress in a marked utterance. 


\author{
a. ISAW her. \\ b. I saw HER, (not HIM.)
}

It seems to be a lexical property of climbing verbs that they do not take nuclear stress in the unmarked case. But given that they may bear main stress in the marked case, it is unlikely that the right way to encode their stress-avoiding characteristic in our grammar would be in terms of a [-stress] feature on the lexical item, just as it is unlikely that English pronouns have such a feature. Ultimately, there must be a lexical semantic property of climbing verbs and pronouns that has the indirect effect that they do not bear main stress in the unmarked case. I leave this issue open here.

Although Hungarian stress-avoiding verbs and English pronouns are similar in their stress-avoiding property (i.e., neither takes neutral main stress), they differ as to how they resolve the conflict that arises if they are placed in a position that would normally receive main stress by the nuclear stress rule of the given language. In English, a prosodic operation, destressing applies and assigns a Weak label to the phonological word containing the pronoun (Neeleman and Reinhart 1998). In Hungarian, in parallel to stress-driven movement, the situation is resolved by stress-avoiding movement: the stress-avoiding verbs trigger the movement of overt material to their left. This constituent can take neutral stress and thus neutral interpretation, as in the case of climbing (see 29), or focal stress and contrastive interpretation (see 30). In particular, climbing involves movement of the most embedded $\mathrm{V}$ or its particle in a series of infinitival complement taking climbing verbs to a position immediately in front of the topmost, finite $\mathrm{V}$.

$$
\begin{aligned}
& \text { SZÉT fogom akarni kezdeni } t_{\mathrm{PRT}} \text { szedni a rádiót. } \\
& \text { PRT will-I want-to begin-to take-to the radio-ACC } \\
& \text { 'I will want to begin to take apart the radio.' }
\end{aligned}
$$

$$
\begin{aligned}
& \text { A RÁDIÓT fogom akarni kezdeni szétszedni t } \mathrm{DP}_{\mathrm{DP}} \\
& \text { the radio-ACC will-I want-to begin-to PRT-take-to } \\
& \text { 'It is the radio that I will want to begin to take apart.' }
\end{aligned}
$$

Climbing is blocked unless all the verbs involved in the sequence (here fogom 'I will', akarni 'to want', kezdeni 'to begin') are climbing verbs; an issue not addressed here. Climbing is also blocked if a constituent is contrastively focused, as in (31a), either in the main clause or in the infinitival clauses (Koopman and Szabolcsi 2000). However, crucially, an intervening quantifier or topic does not block climbing (see 31b).

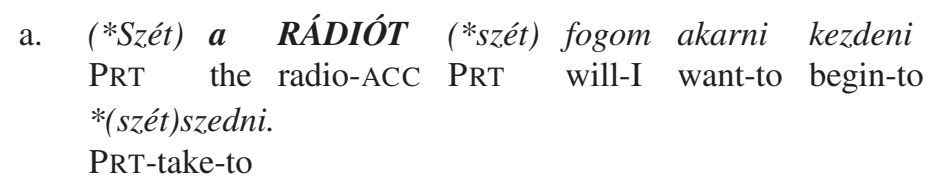


'It is the radio that I will want to begin to take apart.'

b. SZÉT fogom a rádiót akarni kezdeni szedni.

PRT will-I the radio-ACC want-to begin-to take-to

'As for the radio, I will want to begin to take it apart.'

Given the blocking effect between climbing and focusing, it is a natural idea to assume that they compete for the same syntactic position, the [Spec, FP]. ${ }^{16}$ More importantly the blocking effect is due to the fact that once focusing happened, there is no trigger for climbing. Recall that focus-movement happens to ensure that the DP gets stressed, and that climbing happens to ensure that the $\mathrm{V}$ does not get stressed. Clearly, focus-movement alone satisfies both its own need to get stressed and the verb's need not to get stressed. Thus, in sentences with a focused constituent, climbing is ruled out by economy, (19).

To summarise, in (30) [Spec, FP] is licensed by the movement of the verb in order to facilitate stressing of constituents that otherwise would not be in a position to get stress. Or, as in the case of climbing (29), this position can be created to avoid stressing of a constituent that otherwise would get stressed.

\section{Focus and economy}

\subsection{Focus projection}

In (30), the focused constituent is the stressed constituent. But the Stress-focus correspondence principle, (16), allows for cases where the focused constituent contains the stressed constituent. As Kenesei (1998a) describes extensively, such cases do exist. This phenomenon is known as focus projection (cf. Selkirk 1984). In her discussion of the matter, Reinhart (1995) defines the notion of focus set as the set of the possible foci of one particular stress pattern according to the Stress-focus correspondence principle.

In (32)-(34) the neutral stress (cf. 11) is assigned to the leftmost constituent of the FP, i.e., to [Spec, FP], and within [Spec, FP] to the leftmost constituent, i.e., to the head $\mathrm{N}$ in (32) and to the AP modifier in (33)-(34). As a result, the focus set of (32) is $\{[\mathrm{Spec}, \mathrm{FP}], \mathrm{FP}\}$; that of (33) and (34) it is $\{\mathrm{AP}$, [Spec, FP], FP $\}$. As the possible continuations of the sentences indicate, these readings are all available. ${ }^{17}$

16. My analysis takes climbing to be phrasal movement, but note that it is in no way crucial to it whether this is in fact so. If climbing was head movement, blocking could not be a result of the fact that they compete for the same position. However, it would still hold that blocking is due to the fact that there is no trigger for climbing if focusing occurs, as the $\mathrm{V}$ is not clause initial anymore. Exactly this view is taken by Dalmy (1999). As a reviewer notes, if climbing was to be analysed as head-movement, it would be crucial that the particle targets a lexical head position, rather than a functional head, as functional heads are assumed not get stress. 
(32)

a. (Focus: $[$ Spec, FP])

János [ $\mathrm{FP}$ a CIKKEKET olvasta] és nem a

John the articles-ACC read and not the

könyveket.

books

'John read the articles, and not the books.'

b. (Focus: FP)

János [FP a CIKKEKET olvasta] és nem a

John the articles-ACC read, and not the

fürdöszobában énekelt.

bathroom-LOC sang

'John read the articles, and not sang in the bathroom.'

[FP A TEGNAPI cikkeket [F olvasta $]$ [VP János]],... the yesterday's articles-ACC read John

'It was yesterday's articles that John read, . . '

a. ... nem a maiakat. (Focus: adjunct in [Spec, FP]) not the today's-ACC

'... not today's ones.'

b. ... nem a könyveket.

not the books-ACC

(Focus: [Spec, FP])

'... not the books.'

c. ... nem a fürdöszobában énekelt.

(Focus: FP) not the bathroom-LOC sang

'... not sang in the bathroom.'

[FP Péter [FP egy HASZNÁLT autót [F vett]]],...

Peter a second-hand car-ACC bought

'Peter bought a second-hand car, ...'

17. An anonymous reviewer notes that for him/her a wide, sentence-focus reading is unavailable if it is the subject that is fronted (see also Kenesei 1998b). My own judgement is that the sentence is grammatical and appropriate as an answer to the context question in (i). The context indicates that the answer has to have what I term a COMPLEX FOCUS - a focus inside a focus: János 'John' is contrasted with Péter 'Peter' and an all-focus utterance is required as an answer to the question Mi történt? 'What happened?'. See Neeleman and Szendrối (2002) for discussion of complex foci.

(i) Q: Úgy volt, hogy PÉTER bútorozza be a szobát. De nem EXPL was that Peter furnishes PRT the room-ACC but not volt hajlandó segíteni. Mi történt végül? was willing help-to what happened finally 'PETER was supposed to furnish the room. But he was not willing to help. What happened in the end?'

A: JÁNOS készített egy asztalt.

John built a desk-ACC

'JOHN built a desk.' 

a. ... nem egy újat. (Focus: adjunct in [Spec, FP]) not a new-ACC

An anonymous reviewer mentions that according to his/her judgement the availability of the wide readings in (33c) and (34c) is dependent on the choice of the adjective. So, if használt 'second-hand' is swapped for piros 'red' the wide reading is not available. (S)he also suggests that this is due to the fact that használtautó 'second-hand car' is a possible compound noun, which would imply that in (34c) focus projection takes place from the (compound) nominal head rather than the modifier. I do not share the judgement that the wide readings are only available if the modified noun is pronounced as a compound. Moreover, this view would incorrectly predict that wide readings are also available if stress falls on a simplex, modified noun, as in (35).

In (35) main stress falls on the nominal head of the moved DP. As it is shown by the possible continuations of the clause, the focus of the utterance is obligatorily narrow.

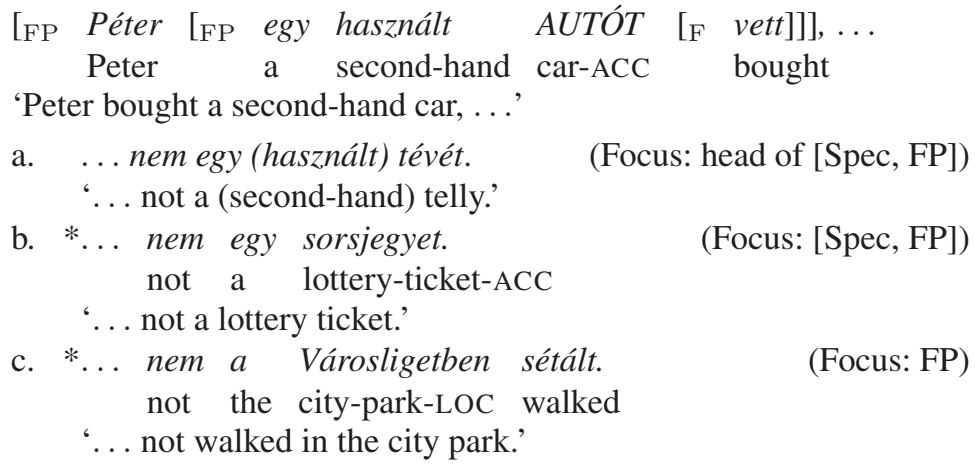

c. *... nem a Városligetben sétált. (Focus: FP)

(Focus: head of [Spec, FP])

(Focus: [Spec, FP])

According to the Stress-focus correspondence principle in (16), any constituent that contains the main stress should be a possible focus of the utterance. Why should the wide focal readings be unavailable in (35)? I argue that this is due to economy in the following sense.

Reinhart (1995) shows cases in English where the only option available for satisfying (16) is by means of an extra prosodic operation. She claims that a special prosodic operation, stress shifting, may assign stress to a position 
which would otherwise not bear the main stress of the utterance. For example, stress may be shifted to the subject in JOHN built a desk. The focus set by (16) would be $\left\{\mathrm{DP}_{\mathrm{JOHN}}\right.$, IP $\}$. In this case, however, not all foci are actually available as possible interpretations of the sentence. The sentence can be uttered to express focus on the subject, but it cannot be uttered out of the blue (i.e., focus on IP). Reinhart (1995) claims that this is due to a straightforward case of economy, (19), which regulates syntactic (including LF) and prosodic operations. IP was already in the original focus set defined by the neutrally stressed John built a DESK, therefore applying the stress shifting rule to put stress on the subject under the IP-focus interpretation would involve an extra, unnecessary operation. ${ }^{18}$

Now, compare (34) to (35) under economy as in (19). They both involve a movement operation (see Section 9.2 on this point). In addition, (35) also involves a stress shifting operation, which shifts the nuclear phrasal stress, assigned by (11a), from the modifier to the nominal head of [Spec, FP]. Under wide (i.e. [Spec, FP], FP) focus, this operation was unnecessary, as the availability of these readings in (34) illustrate.

Note that Hungarian provides an argument in favour of Reinhart (1995) contra the original 'focus percolation'-idea of Selkirk (1984). Selkirk (1984) claimed that if a head $\mathrm{X}$ is marked as focus, the whole XP can be optionally marked as such, and that if a YP which is a complement to $\mathrm{X}$ is marked focus, $\mathrm{X}$ can be marked as such. Thus focus may eventually 'percolate' from a head, or a complement of a head, to the phrase. In contrast, Reinhart (1995) claims that 'percolation', i.e. wide interpretation, is possible from a neutral stress position, but not possible from a special stress position. In the case of Hungarian, the neutral stress position is the specifier of XP, thus focus may 'percolate' from this position. If Selkirk's (1984) focus percolation was adopted for Hungarian (cf. Kenesei 1998b), then it would wrongly predict that (35) should have wide focus interpretations, given that it is the head of the DP that is stressed and marked $[+\mathrm{F}]$ and feature-percolation from heads onto projecting nodes is allowed by Selkirk (1984). ${ }^{19}$

18. Note that the prosodic operation mentioned in Section 6, which allows multiple focus, is not the same as the stress strengthening operation mentioned here. That one results in two main stresses, while this one shifts the single main stress of the utterance from its canonical position to some other position. Thus, even though both operations are subject to economy, in actuality, the argumentation presented here is consistent with the argumentation put forward in Section 6.

19. Note that Kenesei (1998b: Fn 6) (contra Vogel and Kenesei 1990: 360-161; and contra Kenesei and Vogel 1993: 107) takes the 'last unreduced stress' in the phrase to be the phrasal stress. Thus, in a DP, a 'használt 'autót 'the second-hand car-ACC', he interprets the (optional) stress on the noun head as the main one. This is in full accordance with his theory of focuspercolation, which follows Selkirk (1984) in assuming that percolation is possible from heads, 


\section{Kriszta Szendröi}

\subsection{Shortest stress shift}

Kenesei (1998a) also describes cases where the moved constituent is in fact larger than the constituent that is taken as focus at both PF and LF. For instance, this is the case in (35a), where the whole DP moved to the left-periphery, while only the $\mathrm{N}$ head of the DP received focal interpretation.

Note that (35a) raises a problem in its own right. Here we see, contrary to expectations, that the main stress of the sentence is not assigned by the stress rule in (11), but by a special phonological operation, and still the constituent containing it is moved. At first sight, the application of both movement and stress shift might seem to be an economy violation. This is, however, not a real problem, on the contrary, it actually follows from Neeleman and Reinhart's (1998) proposal.

In (35a), the stress falls on AUTÓT 'car' in the DP egy használt AUTÓT 'a used CAR'. This is assigned by a universal stress strengthening rule, which here targets the phonological word corresponding to the head of the fronted DP, as it aims to ensure focusing of the head rather than the modifier. In a treebased metrical system marking a constituent Strong inevitably means marking its sister Weak. Therefore the special stress rule can be formulated as in (36).

\section{Stress strengthening: \\ Assign Strong to a node.}

Following Reinhart's (1995) proposal, I assume that this rule aims to minimize the distance between this stress position and the position of the neutral stress (as of 11). Why this should be so can be illustrated in a tree-based notation of sentential stress. (35a) is repeated here under (37a), and a version where egy használt AUTÓT 'a second-hand CAR' stays in its base position is shown in (37b). For autót 'car' to be only dominated by S-s in its base position, (36) has to apply on more levels of the tree. However, if the DP moves to the left-periphery, only one application of (36) is necessary.

but not from modifiers.

According to the stress rule proposed in (11), the stress falling on the modifier is phrasal stress, while stress on the nominal head is predicted to be word level stress. The crucial fact in favour of this latter view is that no wide focus reading can be obtained if no stress falls on the modifier and there is stress on the noun head: egy használt 'autót 'a second-hand car-ACC' (as in 35). But the wide reading is available once the modifier is stressed. In this case, the noun may also have stress, word level stress, if it is not accessibly discourse-linked. (On this point see also the discussion in Section 11.) In Kenesei's (1998b) analysis nothing accounts for the obligatory stress on the modifier under DP focus. 
(37)

a.

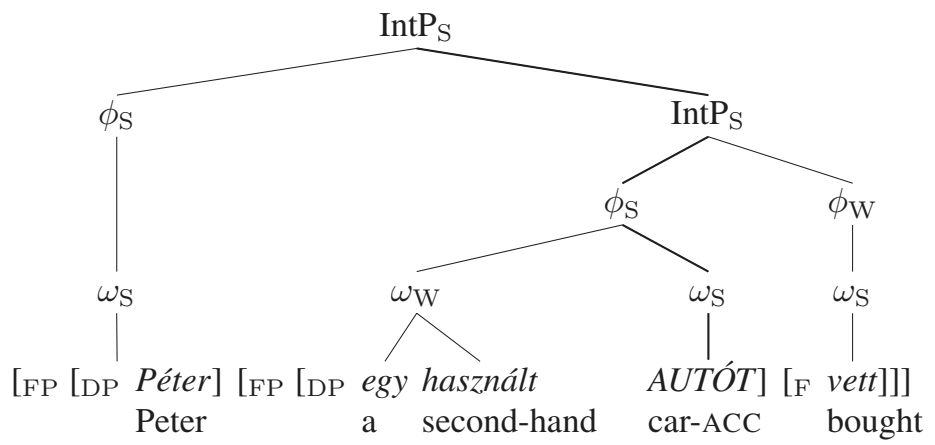

'Peter bought a second-hand CAR.'

b.

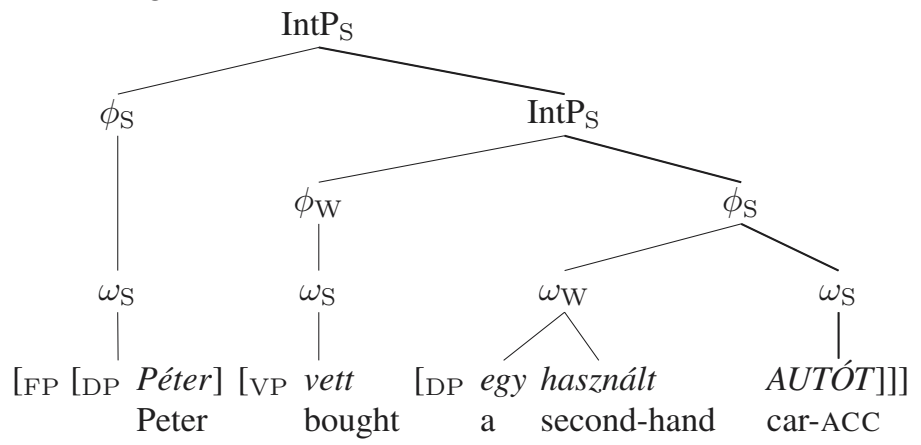

'Peter bought a second-hand CAR.'

A similar problem was noted by Tanya Reinhart (p.c.) for English. Given that in English the neutral stress falls on the object, focusing of the subject always involves a stress shifting operation. The following examples illustrate that the notion of shortest possible stress shift is also at play here. Although both (38a) and (38b) have stress within the $\mathrm{DP}_{s u b j}$, (38b) cannot actually have the interpretation answering the question 'Who committed the murder?' (i.e., Focus $=$ subject). This is so, because the same interpretation can be obtained, as in (38a), by fewer instances (in fact only one instance) of stress shifting operations. Note that in English, syntactic phrases and phonological phrases are mapped by their rightward brackets, and the nuclear stress rule places $\mathrm{S}$ label on the rightmost node in any domain.

a. Focus set: $\left\{\mathrm{DP}_{\text {the gun }}, \mathrm{PP}_{\text {with the gun }}, \mathrm{DP}_{\text {subj }},{ }^{*} \mathrm{IP}\right\} \operatorname{IntP} \mathrm{P}_{\mathrm{S}}$ 


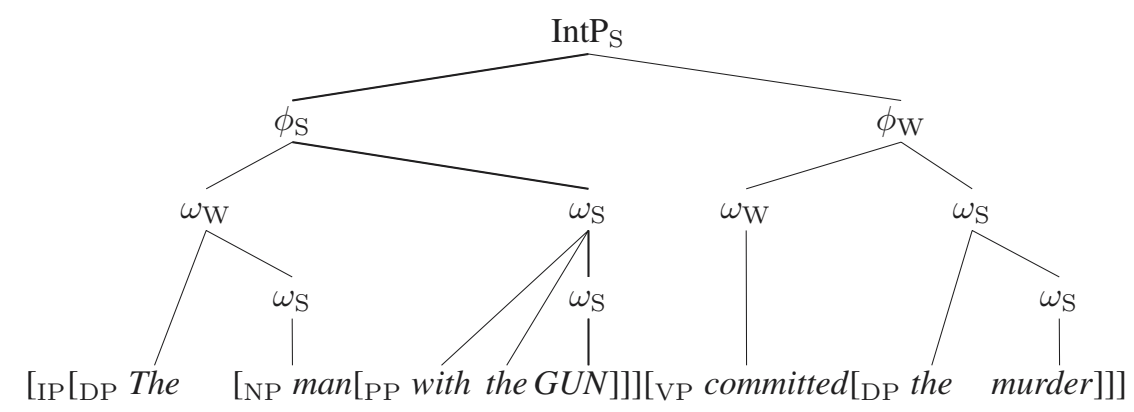

b. Focus set: $\left\{\mathrm{N}_{\text {man }},{ }^{*} \mathrm{DP}_{\text {subj }},{ }^{*} \mathrm{IP}\right\} \operatorname{IntP}_{\mathrm{S}}$

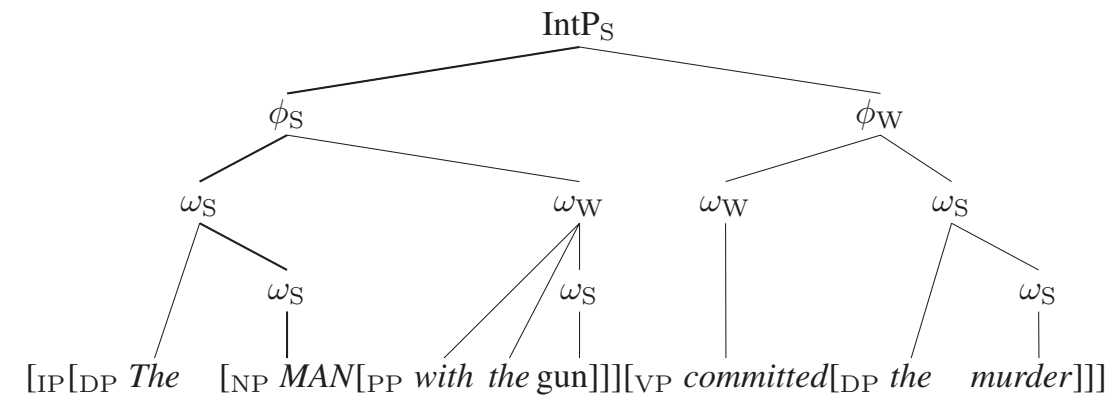

To sum up, I showed above that stress strengthening, (36), is subject to economy, as in (19), in the sense that shortest possible stress shift is preferred both in Hungarian and in English.

\section{Infinitivals}

Let me now return to the case of infinitival clauses which involve a focus. As I have shown in examples (8a) and (8b) above, repeated here for convenience as (39), if a constituent is preposed, both PRT-V and V-PRT orders are possible. Bródy (1990) argued that in the PRT-V order the verb has remained in situ, and in the V-PRT order it has moved to F.
a. Jobb lenne
PÉTERT hívii fel.
better would-be Peter-ACC call-to PRT
b. Jobb lenne PÉTERT felhívni.
better would-be Peter-ACC PRT-call-to
'It would be better to ring up PETER.'

The position known as [Spec, FP] is licensed by the movement of the $\mathrm{V}$ in examples like (39a). However, in examples like (39b) I assume that the head 
position is created and left empty. Recall that the focused constituent cannot be in a position adjoined to VP, it is rather a Spec of a higher head position, for otherwise it would not receive clausal stress. Let me introduce the following assumption (Nash and Rouveret 1997).

An empty head position has to be associated with a categorially matching, overt head at some point in the derivation.

A straightforward way of satisfying (40), also spelt out in Nash and Rouveret (1997: 10-11) is (41). In the case at hand, the V moves to F, as in (39a). An equally straightforward way of satisfying (40) is given in (42).

(41) A categorially matching, overt head raises to the empty head.

(42) The empty head raises to a categorially matching, overt head.

According to Zwart's (1997: 199) analysis of Dutch embedded sentences, in order to satisfy something like (42), AgrS moves to C, as in embedded clauses the V does not move to AgrS. Similarly, in accordance with (42), I claim that the empty F head moves to the higher V in (39b). Of course, (42) is only available here because there is no overt complementizer, which is the case with Hungarian embedded infinitivals in general. ${ }^{20}$ Thus the assumption in (40) provides us with a tool to explain the optionality found in (39). In root contexts, or in embedded clauses with a complementizer, only (41) is available, hence the obligatory V-to-F movement. In infinitivals either the V moves to F, as in (39a) or the F head moves to the higher V, as in (39b).

The optionality found in infinitivals does not contradict the view of economy assumed here. Economy rules out unnecessary operations: whether V moves to $\mathrm{F}$ or $\mathrm{F}$ moves to $\mathrm{V}$, one movement operation is performed. The choice between the two possibilities is irrelevant for economy.

\section{Focus and discourse-linking}

I would like to briefly examine the classification of É.Kiss (1998b) that foci are either identificational or indicate new information. É.Kiss (1998b: 248) argues that the distinction between the two types of focus, identificational and (new)

20. As an anonymous reviewer points out, here it is necessary that the postverbal clause is in fact VP-internal. This is consistent with the assumption made earlier that subjects in Hungarian are VP-internal (cf. É.Kiss 1994). It can also be made consistent with the assumption that a designated subject position is preceded by the V at S-structure (cf. Marácz 1989), if clausal subjects are exempted from movement into this position. For instance, if movement of the subject to [Spec, IP] is triggered by case requirements, then it is expected that an infinitival clause-subject, which does not require case, may remain in situ. 


\section{$64 \quad$ Kriszta Szendröi}

information focus, is observable in the grammar as it correlates with a cluster of syntactic differences. In particular, É.Kiss claims that preverbal focus in Hungarian is a result of focus-movement to a designated focus-position and as a result an identificational focal interpretation is assigned to the moved constituent. New information focus, on the other hand, is post-verbal, and does not involve movement. I believe that the Hungarian data do not warrant the claim that both groups involve focus.

In this paper I argued for a view of focus, along the lines of Reinhart's Stressfocus correspondence principle. I would like to show that what É.Kiss calls new information focus in Hungarian is in fact not that, but rather it is nonaccessibly discourse-linked status in Ariel's (1990) sense under a wide, VPfocus. I will also argue that postverbal constituents do not receive main stress and therefore do not fall under the realm of the Stress focus correspondence principle. Main stress falls on the verb (or a perverbal focus if there is one). Postverbal constituents get phrasal (or secondary) stress if they are not accessibly discourse-linked in Ariel's (1990) sense. But this does not effect the focus of the utterance.

\subsection{What is focus?}

Just like I did earlier (see also Roberts 1998), É.Kiss (1998b) adopts a standard assumption in the literature that the focus of an utterance can be identified by a question-answer pair. This is in fact the only characteristics that she gives that identificational and new informational foci share. I would like to show, that closer study of the data shows that this property does not support a claim that there are two types of focus in Hungarian.

É.Kiss (1998b: 247) claims that (43a) contrasts with (43b) in that the first involves identificational focus on the indirect object Marinak 'Mary-DAT', whereas the same constituent bears new information focus in (43b). She also claims that in (43b) the indirect object and the verbal complex both bear pitch accent. However, in the rest of the paper she ignores the obligatory pitch accent on the verbal complex, which is present in all unmarked Hungarian utterances.

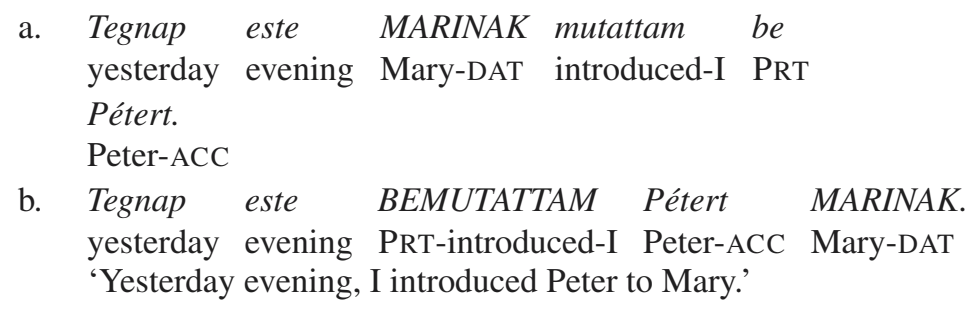

Note that the utterance in (43b) is only well-formed in a context where the 
object Pétert 'Peter-ACC' is accessible to both the hearer and the speaker. For example, if the speaker is Peter's host in a foreign city and his job is to take care of him. The utterance may be part of a dialogue between the host and his boss reporting on his activities concerning Peter's welfare. If Peter is not already accessibly present in the discourse-context, the utterance is inappropriate unless Pétert 'Peter-ACC' also receives stress, as in (44). I will return to this point in Section 11.3.

$$
\begin{array}{llll}
\text { Tegnap este } & \text { BEMUTATTAM PETERT } & \text { MARINAK. } \\
\text { yesterday evening } & \text { PRT-introduced-I Peter-ACC } & \text { Mary-DAT } \\
\text { 'Yesterday evening, I introduced Peter to Mary.' } &
\end{array}
$$

If É.Kiss' (1998b) claim was right and the utterances in (43a) and (43b) involved identificational and new information focus on the indirect object respectively, then one would expect that both (43a) and (43b) are felicitous answers to the question in (45). This is not the case. (43b), shown in (45c), is only marginally available as an answer to the question in (45a), while (43a), repeated in (45b) is an appropriate answer.

$$
\begin{array}{clll}
\text { a. Q: } & \text { Kinek mutattad be Pétert? } \\
& \text { who-DAT introduced-you PRT Peter-ACC } \\
& \text { 'Who did you introduce Peter to? } & \\
\text { b. A: } & \text { Tegnap este MARINAK mutattam be } \\
& \text { Yesterday evening Mary-DAT introduced-I PRT } \\
& \text { Pétert. } \\
& \text { Peter-ACC } \\
\text { c. A': ?\#Tegnap este BEMUTATAM Pétert } \\
\text { Yesterday evening PRT-introduced-I Peter-ACC } \\
\text { MARINAK. } \\
\text { Mary-DAT } \\
\text { 'Yesterday evening, I introduced Peter to MARY.' }
\end{array}
$$

É.Kiss (1998b: 250) claims that the following question-answer pair in (46a)(46b) forms a felicitous discourse. She admits that the answer is "less commonly" used in this context than the one in (46c) where the object is the identificational focus of the utterance. In fact she indicates in the translation that the answer in (46b) is only felicitous if the speaker intends to signal that the answer was not exhaustive.
a. A: Hol jártál a nyáron? ${ }^{21}$
where have-you-been the summer-LOC
'Where have you been over the summer?'
b. B: Jártam OLASZORSZÁGBAN.
have-been-I Italy-LOC




\author{
'I went to Italy [among other places].' \\ c. B': OLASZORSZÁGBAN jártam. \\ 'I went to ITALY.' (É.Kiss: 1998b Ex. 11; my glosses)
}

The verb jártam can be most appropriately translated into English as 'I have been to'. Just like English behave it selects an obligatory adverbial. Due to its semantic emptiness jártam does not bear main stress in the unmarked case, just like English grow (cf. Bolinger 1972). If the utterance in (47b) is pronounced out-of-the-blue, as in (47), the adverbial obligatorily appears in front of the verb, (47a). This is presumably the same phenomenon that I described in the case of climbing verbs in Section 8.
a. OLASZORSZÁGBAN jártam.
Italy-LOC
have-been-I
b. *JÁRTAM Olaszországban. 'I have been to Italy.'

Thus this lexical property of the verb (and also the context question; see Fn. 21) favours the availability of the reading with postverbal focus. According to my judgments, if almost any other verb is used, as in (48), the questionanswer pair with neutral intonation and postverbal focus is ungrammatical.

a. Q: Hol nyaraltál a nyáron?

where had-holidays-you the summer-LOC

'Where did you have holidays this summer?'

21. Note that the choice of the context question is slightly unfortunate, as, given our worldknowledge, it can be easily interpreted as 'What did you do over the summer?', allowing for VP- rather than adverbial-focus interpretation in the answer. If we control for this, the postverbal, adverbial-focus is unavailable unless an interjection like például 'for example' is added.

(i) Context: Martians invaded Earth. They are known to have been to many places. In fact, them being Martians, they can be in more then one place at the same time.
A: Hol jártak a marslakók tegnap?
where have-been-they the Martians yesterday 'Where did the Marsmen go yesterday?'
B: A marslakók tegnap jártak *(például)
the Marsmen yesterday have-been-they for-example OLASZORSZÁGBAN.
Italy-LOC
'Yesterday, the Marsmen have been to ITALY.' 
b. A:

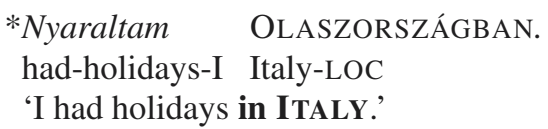

There is, however, one intonation of (48b) that is appropriate in the context of (48a). In this intonation, the verb is pronounced with characteristic leftdislocation intonation: low tone with a sharp rise at the end. The utterance improves further if an interjection, such as például 'for example' is added, as in $(48 \mathrm{c})$.

c. $\mathrm{A}^{\prime}$ :

NYARALTAM, például OLASZORSZÁGBAN.

had-holidays-I for-ex. Italy-LOC

'As for having holidays, I had them, for example, in

ITALY.'

Note that (48c) supports É.Kiss' claim that the postverbal focus pattern does not involve exhaustive listing. If például 'for example' can be added, it cannot be the case that the focus of the answer gives an exhaustive answer. To the contrary, it only gives an example. This intonation is the 'hat' intonation contour discussed for instance by Büring (1997). A closer study of the utterance with 'hat'-intonation and the availability of an interjection suggesting non-exhaustivity is left for future research.

É.Kiss' (1998b: 249) gives another example to illustrate the identificational vs. information focus distinction. She claims that the postverbal object in the utterance in (49b) 'introduces new, nonpresupposed information'. Nevertheless, she admits that the $\mathrm{V}$ (also) receives a pitch accent.
a. János és Mari VÁSÁROLNAK. 'John and Mary are shopping.'
b. Mari KINÉZETT magának egy KALAPOT.
Mary PRT-spotted herself-DAT a hat-ACC
'Mary spotted for herself a hat.'
É.Kiss (1998b: 249; my translation)

Although it is true that in (49b) the object carries nonpresupposed information, that in itself is not enough to claim that the object carries new information focus. By É.Kiss' own test, a focus must be a possible answer to a corresponding question. (49b), however, does not seem to be appropriate as an answer to a question on the object, as is illustrated in (50a-b). Even if it is marginally appropriate, $(50 \mathrm{c})$ is much more natural in the context.

a. Mit nézett ki magának Mari?

'What did Mary spot for herself?' 
b.

\begin{tabular}{lllll} 
?\#Mari KINÉETT magának egy & KALAPOT. \\
Mary PRT-spotted herself-DAT a hat-ACC \\
\hline Mari egy KALAPOT nézett
\end{tabular}

But if (49b) does not involve focus on the postverbal object, then what is the focus of (49b)? What the context sentence in (51a) indicates is that we are talking about Mary and John, enumerating what they have done. The discourse in (51) is perfectly parallel to the one in (49) from a pragmatic point of view. They both involve VP-focus on all the utterances.

a. János és Mari VÁSÁROLNAK.

John and Mary shop-they

'John and Mary are shopping.'

b. Mari ELKÖLTÖTTE az ÖSSZES pénzét.

Mary PRT-spent the all money-her-ACC

'Mary has spent all her money.'

c. János UNJA a banánt és végre HAZA

John is-bored the banana-ACC and finally home

akar menni.

wants go-to

'John is really bored and annoyed and wants to finally go home.'

It seems to be the case that the stress on the object in (51b) is irrelevant for determining the focus of the utterance. The fact that the verb is stressed in all these cases supports the claim that the verb, but not the postverbal constituents, carries main stress. The focus of the utterances in (49) and (51) is on the VP. I would like to propose that the stress on the postverbal object in (49b) is phrasal stress that simply indicates that the DP is not accessibly discourse-linked.

If so, then we understand why all the utterances involving alleged postverbal new information focus are not or only marginally available as answers to corresponding questions (cf. 45c, 48b, 50b). The postverbal constituent bears phrasal stress indicating that it represents information not yet (or not accessibly) present in the discourse. Intuitively, an answer to a question has to supply the information indicated by the question word. This requirement is satisfied in (45c), (48b) and (50b). However, in order to form a well-formed discourse, the relevant material has to be the focus of the answer. This is not the case in these examples, as they involve wide, VP-focus, hence their marginality. 


\subsection{On phrasal stress in Hungarian}

Let me now argue for the claim that postverbal constituents do not bear main stress in Hungarian, and therefore cannot be (new information) foci. Let us start by a brief review of different approaches to Hungarian stress in the literature. Vogel and Kenesei $(1987,1990)$ present an approach based on prosodic structure, however their syntax-phonology mapping rules are different from the ones presented here. É.Kiss (1992: 93) takes the view that stress is assigned to syntactic structure. All of these approaches (and the view presented in this paper) agree that stress in Hungarian is leftward-oriented in any given domain.

Kálmán and Nádasdy (1994) present a very different approach to stress. In effect they claim that there is no single main stress in the Hungarian utterance, rather each phrase bears equal stress. The main stress on the verb or the preverbal focus is uncontested in any theory. The issue relevant here is whether the stresses on the postverbal constituents are main stresses. If it turns out that the stress on a postverbal constituent is main stress, then, according to the Stressfocus correspondence principle (16), the prediction is that these are possible foci. On the other hand, if it turns out that these do not take main stress, then the prediction is, that postverbal constituents do not bear the focus of their utterance, contra É.Kiss (1998b). To test this, let us see whether it is possible to omit the stress on postverbal constituents under wide, VP-focal interpretation.

Kálmán and Nádasdy (1994: 411) show that if the phrasal stress of the object is omitted, the utterance cannot be interpreted with wide, VP-focus, see (52b). This, they claim, suggests that the stress on the object is main stress.
a. A: Mit csinált?
what did-he
'What did he do?'
b. B: FIZIKÁT tanult a BUSZON.
c. $\mathrm{B}^{\prime}$ : \#FIZIKÁT tanult a buszon.
physics-ACC studied the bus-LOC
'He studied PHYSICS on the BUS.'

But observe that, in (53), wide focus is available without stress on the object.
a. A: Mi van a fiaddal?
what is the son-your-with
'What's the news about your son?'
b. B: JÓL vannak a gyerekeim.
well are-they the kids-my
'My kids are WELL .'

Neeleman and Reinhart (1998) argued that discourse-linked material (i.e., material that is accessible in the previous discourse in Ariel's 1990 sense) is 


\section{$70 \quad$ Kriszta Szendrối}

obligatorily destressed and vice versa, material that is destressed is discourselinked. So (52b) is simply inappropriate because it contains a destressed element buszon 'bus-LOC' that is not accessibly discourse-linked. In addition, Tanya Reinhart (p.c.) claims that if a set is present in the previous discourse, the superset is accessible in Ariel's (1990) sense. As the set denoted by gyerekeim 'kids-my' is a superset of the set denoted by fiad 'son-your', we expect that mentioning the latter makes the former accessibly discourse-linked. In this light, it is not surprising that (53) is a felicitous discourse. In sum, what (52) and (53) show is that phrasal stress on the postverbal constituent can be omitted under wide focal interpretation so long as the destressed constituent is accessible in the discourse.

This point is further emphasized by (54). In (54) the meaning of the answer is different in the two cases: if the object lacks phrasal stress, the phonology paper is interpreted as one of the term papers; if the object is stressed, the term papers are interpreted as denoting a set that does not contain the phonology paper. Nevertheless, both utterances have wide focus, as indicated by the question in (54a). (In fact the different intonations indicated on the English translations allow for the same interpretative difference in English.) In sum, phrasal stress on the object implies that the set denoted by szemináriumi dolgozataimon 'term papers-my-LOC' is not a superset of the set denoted by fonológia esszéddel 'phonology paper-your-INST', while destressing szemináriumi dolgozataimon 'term papers-my-LOC' implies that fonológia esszéddel 'phonology paper-your-INST' is a member of the set denoted by szemináriumi dolgozataimon 'term papers-my-LOC'.

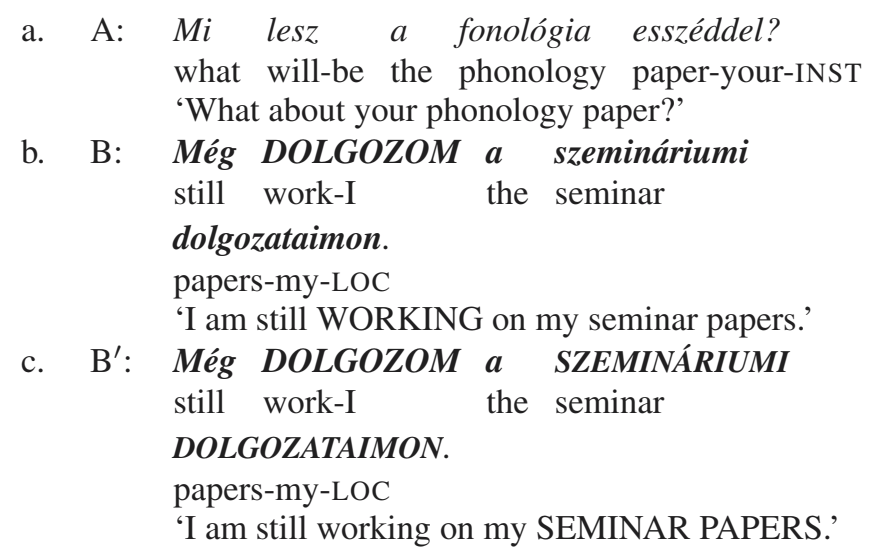

Thus it seems to be an entirely independent issue whether any postverbal constituent bears phrasal stress under wide focus. The only main stress is on the verb (or the preverbal focus, if there is one). 
Let me now come back to a point made earlier. In (44), repeated here as (55) with phrasal stress marked by small caps, I showed that the out-of-the-blue, allfocus pronunciation of the utterance is where there is stress on the $\mathrm{V}$ and on all the postverbal constituents. ${ }^{22}$ In this section I argued that in fact the postverbal constituents bear phrasal stress, while the stress on the verb is main stress (see $55)$.

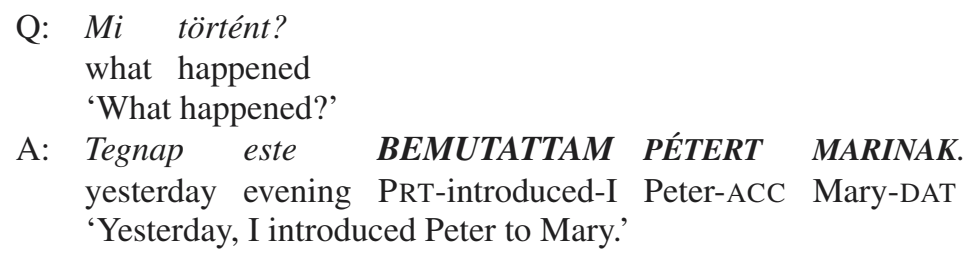

If so, we make the following prediction. In (56) it is assumed that a kis Pétert 'the little Peter-ACC' is one of the speaker's children. (56b) is marginally available as an answer to (56a) as it contains the relevant information indicated by the question word. However, (56c) is totally inappropriate in the context of (56a), as it contains an element that is unstressed even though it is not accessibly discourse-linked. This is explained by the generalisation that the presence of a set in the discourse does not render any of its subsets accessible (Tanya Reinhart p.c.).
a. Kinek mutattad be a gyerekeidet?
who-DAT introduced-you PRT the children-your-ACC
'Who did you introduce your children to?'
b. ?\#BEMUTATTAM a gyerekeimet MARINAK.
PRT-introduced-I the children-my-ACC Mary-DAT
'I introduced my children to Mary.'
c. \#BEMUTATTAM a kis Pétert MARINAK.
PRT-introduced-I the little Peter-ACC Mary-DAT
'I introduced the little Peter to MARY.'

In this section I provided arguments in favour of the claim that postverbal constituents in Hungarian bear phrasal stress if they are not discourse-linked to an accessible entity in the previous discourse, but they do not bear main stress. As a result they are not subject to the Stress-focus correspondence principle and they do not receive new information (or any other) focus interpretation, which correctly derives the fact that utterances containing a postverbal, phrasal stress form felicitous answers to a $w h$-question only marginally (or not at all).

22. The subject in (55) is pro-dropped. The speaker being a center of the discourse is always accessibly discourse-linked (see, e.g., Erteschik-Shir 1997), so its presence or absence is irrelevant for the discussion here. 


\subsection{Discourse-linked verb}

In Section 11.1 I claimed that the marginality of (45c), (48b) and (50b) was due to the fact that they did not bear focus on the postverbal constituents, as these only had phrasal - but not main stress, and that the focus of these utterances was on the VP. So far I have shown that the stress on the postverbal constituents is phrasal stress and main stress falls on the verb. Let me argue for the latter claim here, namely, that (45c), (48b) and (50b) have VP-focus interpretation.

Recall the example in (50b) repeated here as (57b). As (57a) shows, this utterance is perfectly felicitous in a context indicating VP-focus.

a. Mit csinált Mari?

what did Mary

'What did Mary do?'

b.

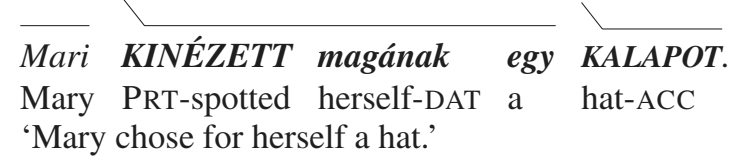

I argued that even though the utterance in (57b) has VP-focus, it is marginally acceptable in a context indicating $\mathrm{DP}_{\mathrm{DO}}$ focus, as the object in (57b) is new to the discourse. The following test can be applied to provide further evidence for this claim. In a context where the verb itself is discourse-linked, (57b) should be inappropriate if it indeed has VP-focus. On the other hand, if É.Kiss is right and it has focus on the postverbal $\mathrm{DP}_{\mathrm{DO}}$, then destressing and discourse-linking the verb should not make any difference.

Let us imagine the following situation. A group of people take part in a game in the course of which it will be revealed how well they know each other. According to the rules of the game, they have to enter a room full of theatrical equipment, look around and choose some objects that they think are characteristic of themselves. Then they come out and there is a discussion on who chose what and why. Two people have the following exchange about this game.

a. A: Bementek. Mindannyian kinéztek néhány dolgot. Mit nézett ki Mari?

'They entered. They all chose some things. What did Mary choose?'

b. B:

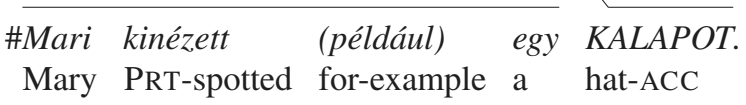


c. $\mathrm{B}^{\prime}$ :

\begin{tabular}{llll}
\hline Mari egy & KALAPOT & nézett & ki. \\
Mary a hat-ACC & spotted & PRT \\
'Mary chose a hat.' & &
\end{tabular}

The inappropriateness of (58b) in the context of (58a) shows that a postverbal DP may not receive main stress even if the verb is discourse-linked. Thus it may not receive focus interpretation either, rendering the exchange in $(58 \mathrm{a}-\mathrm{b})$ infelicitous.

To conclude, closer study shows that the Hungarian data does not support É.Kiss' identification vs. new information focus distinction. The marked, postverbal focus pattern in Hungarian, to the extent that it occurs at all, is only possible when the verb itself is prosodically left dislocated (cf. 48c). Otherwise, stress may be heard on a postverbal object under wide, VP-focus, if the object is not accessibly discourse-linked. As I argued above, this does not actually put focus on the object. Rather, as I argued earlier, contra Kálmán and Nádasdy (1994), it receives phrasal stress. Main stress falls on the verb.

Let me also mention here that, É.Kiss' insight (see also Horváth 2000) is probably on the right track in the following sense: it is most probably due to the presence vs. absence of movement in the two constructions that postverbal focus (if possible, as in 48c) is interpreted non-exhaustively, whereas preverbal foci are exhaustive in Hungarian. This issue is left open for future research.

\section{Conclusion and consequences}

The aim of this paper was to show that the Stress-focus correspondence principle (16) of Reinhart (1995), originally proposed for English and Dutch, is a powerful tool in accounting for a range of data in Hungarian, a language with focus-movement.

In particular, it explains why the focus moves to the left-periphery in Hungarian. This is so, because nuclear stress in Hungarian is leftward-oriented. In a language with right-peripheral stress, stress-driven focus movement is expected to be right-peripheral. (As I showed in Szendrôi (2002), this is indeed the case in Italian.)

Second, the approach also accounts for the fact that Hungarian focus movement targets a specifier position. If it was adjunction, the stress rule would treat it as it treats topics. Therefore, main stress would not fall on the left-peripheral focus.

Third, the approach also shows why focus movement is necessarily overt. Given that it is a PF requirement that the focus be left-peripheral in the clause, covert movement has no effect on the focus of an utterance. 


\section{$74 \quad$ Kriszta Szendröi}

Fourth, the approach accounted for the uniqueness of the syntactic focus position, as opposed to the recursive topic and quantifier positions at the leftperiphery of the Hungarian clause. This follows from the simple fact that given the nuclear stress rule, there is one single position in the clause where main stress falls.

Fifth, the approach also gives a straightforward explanation for the fact that verb focusing in Hungarian does not involve separation of the verbal particle from the verb. Given that V-movement always strands the particle, the fact that the PRT-V order is undisturbed in this case suggests that the verbal complex remains in situ. This is to be expected in the present approach, as the verbal complex is in the position where nuclear main stress falls in the utterance by the nuclear stress rule.

Sixth, I also accounted for the blocking effect between focusing and particle climbing observed by Koopman and Szabolcsi (2000).

Seventh, I showed that the analysis extends to cases described in Kenesei (1998a) where there is a discrepancy between the moved constituent and the focus of the utterance. In particular, I accounted for the phenomenon of focus projection, as wide focus readings are by definition available, unless ruled out by economy. I also accounted for the fact that the focused constituent is moved to the left-periphery, even if stress is shifted within the constituent itself.

Finally, I showed that this approach is not inconsistent with É.Kiss' (1998b) classification of different types of foci, if in addition to focus, another information packaging device, discourse-linking, is also taken into consideration.

On the basis of the above discussion I conclude that the assumption of a [+Focus]-feature is unnecessary to account for Hungarian focus movement data.

Having accepted a stress-based approach to focus-movement, my analysis faces two theoretical issues.

First, where in the grammar does the Stress-focus correspondence principle, (16), apply? In order to find at least a tentative answer to this question, one has to establish where in the grammar the notions that (16) refers to are defined. Such notions are stress and focus. As Zubizarreta (1998: 30) points out, these notions are intrinsically non-lexical, as they are defined over the structure, which is non-existent in the lexicon. These notions cannot be lexical, or be put together from atomic parts which are themselves lexical. So I conclude that the architecture of the grammar has to be such that it allows for the postulation of these notions, and of principles referring to these notions. (See Szendrói 2001 for more discussion.)

Stress is normally assumed to be a notion defined over the prosodic structure on the way to PF. No [+stress] lexical feature is generally assumed. If this is indeed the case, then it is even more natural to get rid of its semanticopragmatic counterpart: the [+Focus]-feature. 
As far as the notion focus is concerned, I assume that it is a discourse notion. Since, as I argued in this paper, neither stress nor focus are encoded by syntactic features, the Stress-focus correspondence principle, (16), which refers to both these notions, will have to apply where both stress and focus are available. I would like to propose, in line with much recent work (cf. Bródy 1995b; Chomsky 1995: 220; Jackendoff 1997; Reinhart 1995; Williams 1997, 2000), that at the interface between the grammar and the conceptual system, both prosodic and syntactic information is available, and principles such as (16) apply here. Essentially, I would like to assume that this is where certain discourse considerations operate. (A more detailed discussion of the theoretical consequences of this approach, including a comparison with an analysis based on the syntactic [+Focus]-feature, is given in Szendrói 2001).

Note that what I have said above does not imply that pragmatic considerations may drive syntactic operations. They may only indirectly do so if they themselves are formally encoded in LF or PF notions present in the core grammar, otherwise they are not available at the interface. So, for instance, the utterance It's cold here. uttered by a guest to his hostess may very well have the pragmatics that he wishes her to switch on the heating, but there is no welldefined phonological or syntactic clue in the utterance that would determine (or at least allow for; in the weak sense) this interpretation. It is largely due to our world knowledge and maybe partially to universal principles operating in pragmatics that we conclude that the given interpretation is the one the speaker was most probably intending to communicate. Precisely these kinds of pragmatic considerations do not have an effect on syntactic structure. On the other hand the discourse principle spelt out in (16) relies on PF and LF notions, and not on world knowledge, thus it may very well be available at the interface between the grammar and the conceptual systems, and thus may have an effect on syntax and/or phonology.

Utrecht University

\section{References}

Ackema, Peter (1995). Syntax below zero. Ph.D. dissertation, Utrecht: OTS, Utrecht University.

Ariel, Mira (1990). Accessing Noun Phrase Antecedents. London: Routledge.

Arregi, Karlos (2001). Focus and word order in Basque. Ms. MIT, November 2001.

Bolinger, Dwight (1972). Accent is predictable (if you are a mind reader). Language 48: 633-644.

Bródy, Michael (1990). Some remarks on the focus field in Hungarian. UCL Working Papers in Linguistics 2: 201-225.

- (1995a). Focus and checking theory. In Levels and Structures, Approaches to Hungarian 5, István Kenesei (ed.), 31-43. Szeged: JATE.

- (1995b). Lexico-logical form. Cambridge, Mass.: MIT Press. 


\section{$76 \quad$ Kriszta Szendröi}

- (1997). Mirror Theory. In UCL Working Papers in Linguistics 9, Philip Backley and John Harris (eds.), 179-222. London: University College London.

Büring, Daniel (1997). The meaning of topic and focus. - The 59th Street Bridge Accent. London: Routledge.

- (2001). Let's Phrase It! - Focus, word order, and prosodic phrasing in German double object constructions. In Competition in Syntax. (= Studies in Generative Grammar 49), Gereon Müller and Wolfgang Sternefeld (eds.), 69-105. Berlin/New York: de Gruyter.

Büring, Daniel and Rodrigez Gutiérrez-Bravo (2001). Focus-related word order variation without the NSR: A prosody-based crosslinguistic analysis. Manuscript. Available at http://www. linguistics.ucla.edu/people/buring/locker/bur_gut.pdf.

Chen, Matthew Y. (1987). The Syntax of Xiamen Tone Sandhi. Phonology Yearbook 4: 109-150.

Chomsky, Noam (1995). The Minimalist Program. Cambridge, Mass.: MIT Press.

Cinque, Guglielmo (1993). A null theory of phrase and compound stress. Linguistic Inquiry 24: 239-267.

Costa, João (2002). Multiple focus in European Portuguese: apparent optionality and subject positions. In Proceedings of Going Romance 2000, Claire Beyssade, Reineke Bok-Bennema, Frank Drijkoningen and Paola Monachesi (eds.), 93-108. Amsterdam/ Philadelphia: John Benjamins.

Dalmy, Gréte (1999). PF-movement by last resort in Hungarian. In Proceedings of DOXIMP 3: Graduate students' third linguistic symposium (June 5, 1998, Budapest) (=Working Papers in the Theory of Grammar 6: 3), Viktor Trón (ed.), 51-81. Budapest: ELTE Theoretical Linguistics Program.

Dezső, László (1974). Topics in syntactic typology. In Linguistica Generalia Vol. 1: Studies in Linguistic Typology, Milan Romportl, Vladimír Skalička, Jaroslav Popela and Bohumil Palek (eds.), 191-210. Prague: Charles University.

É.Kiss, Katalin (1992). Az egyszerú mondat szerkezete [The structure of the root clause]. In Strukturális magyar nyelvtan 1: Mondattan [Structural grammar of Hungarian 1: Syntax], Ferenc Kiefer (ed.), 79-178. Budapest: Akadémiai Kiadó.

- (1994). Sentence structure and word order. In The Syntactic Structure of Hungarian, Ferenc Kiefer and Katalin É.Kiss (eds.), 1-90. San Diego, California: Academic Press.

- (1998a). Multiple topic, one focus? Acta Linguistica Hungarica 45: 3-29.

- (1998b). Identification focus and information focus. Language 74: 245-273.

Erteschik-Shir, Nomi (1997). The Dynamics of Focus Structure. Cambridge: Cambridge University Press.

Fox, Danny (1994). Economy and scope. Natural Language Semantics 3(3), 283-341.

Ghini, Mirco (1993). F-formation in Italian: A new proposal. Ms. University of Toronto.

Harlig, Jeffrey and Kathleen Bardovi-Harlig (1988). Accentuation typology, word order, and theme-rheme structure. In Studies in Syntactic Typology, Michael Hammond, Edith A. Moravcsik and Jessica R. Wirth (eds.), 125-146. Philadelphia: John Benjamins Publishers.

Horváth, Júlia (2000). Interfaces vs. the computational system in the syntax of focus. In Interface strategies, Hans Bennis \& Martin Everaert (eds.). Amsterdam: HAG.

Inkelas, Sharon (1989). Prosodic constituency in the lexicon. Doctoral dissertation. Stanford: Stanford University.

Inkelas, Sharon and Draga Zec (1995). Syntax-phonology interface. In Handbook of Phonology, John Goldsmith (ed.), 535-549. Cambridge, Mass.: Blackwell.

Jackendoff, Ray (1997). The Architecture of the Language Faculty. Cambridge, Mass.: MIT Press.

Kálmán, C. György, Kálmán László, Nádasdy Ádám and Prószéky Gábor (1989). A magyar segédigék rendszere [The system of Hungarian auxiliary verbs]. Általános Nyelvészeti Tanulmányok 17: 49-103.

Kálmán, László and Ádám Nádasdy (1994). A hangsúly [Stress]. In Strukturális magyar nyelvtan 2: Fonológia [Structural grammar of Hungarian 2: Phonology], Ferenc Kiefer (ed.), 393-467. Budapest: Akadémiai Kiadó. 
Kenesei, István (1998a). On the syntactic options of focus. Ms. JATE, Szeged.

- (1998b). Adjuncts and arguments in VP-focus in Hungarian. Acta Linguistica Hungarica 45 (1-2): 61-88.

Kenesei, István and Irene Vogel (1993). A fókusz fonológiai szerkezete. [The phonological structure of focus.] Ms. JATE, Szeged and University of Delaware.

Komlósy, András (1992). Régensek és vonzatok [Heads and arguments]. In Strukturális magyar nyelvtan 1: Mondattan [Structural grammar of Hungarian 1: Syntax], Ferenc Kiefer (ed.), 299-527. Budapest: Akadémiai Kiadó.

Komlósy, András and Farrell Ackerman (1983). Several steps toward an understanding of Hungarian word order. In Proceedings in Memory of Antal Klemm.

Koopman, Hilda and Anna Szabolcsi (2000). Verbal Complexes. Cambridge, Mass.: MIT Press.

Koster, Jan (1975). Dutch as an SOV language. Linguistic Analysis 1: 111-136.

Laka, Itziar (1990). Negation in syntax: On the nature of functional categories and projections. Ph.D. dissertation. MIT.

Liberman, Mark (1975). The intonational system of English. Ph.D. dissertation. MIT. (also 1979 New York: Garland Press.)

Liberman, Mark and Alan Prince (1977). On stress and linguistic rhythm. Linguistic Inquiry 8: 249-336.

Marácz, László Károly (1989). Asymmetries in Hungarian. PhD. dissertation, Groningen University, The Netherlands.

McCarthy, John and Alan Prince (1993). Generalised alignment. In Yearbook of Morphology 1993, Geert Booij and Jaap van Merle (eds.), 79-154. Dordrecht: Kluwer.

Miller, Philip, Geoffrey Pullum and Arnold Zwicky (1997). The principle of phonology-free syntax: Four apparent counterexamples in French. Journal of Linguistics 33: 67-90.

Nash, Lea and Alain Rouveret (1997). Proxy categories in phrase structure theory. In Proceedings of NELS 27, Kiyomi Kusumoto (ed.), 287-304. Montreal: McGill University.

Neeleman, Ad (1994). Complex predicates. Ph.D. dissertation, Utrecht: OTS, Utrecht University.

Neeleman, Ad and Tanya Reinhart (1998). Scrambling and the PF-interface. In The Projection of Arguments: Lexical and Compositional Factors, Miriam Butt and Wilhelm Geuder (eds.), 309-353. Chicago: CSLI Publications.

Neeleman, Ad and Kriszta Szendrői (2002). Superman sentences. OTS Working Papers in Theoretical Linguistics 02-001, Utrecht: OTS, Utrecht University.

Neeleman, Ad and Hans van de Koot (2002). The configurational matrix. Linguistic Inquiry 33 (4): 529-574.

Neeleman, Ad and Fred Weerman (1999). Flexible Syntax - A Theory of Case and Arguments. Dordrecht: Kluwer.

Nespor, Marina and Irene Vogel (1986). Prosodic Phonology. Dordrecht: Foris.

Ortiz de Urbina, Jon (1999). Focus in Basque. In The Grammar of Focus, Georges Rebuschi ad Laurice Tuller (eds.), 311-333. Amsterdam: John Benjamins

Ouhalla, Jamal (1994). Focus in Standard Arabic. Linguistics in Potsdam 1: 65-92.

Reinhart, Tanya (1995). Interface strategies. OTS Working Papers in Theoretical Linguistics 95002, Utrecht: OTS, Utrecht University.

Rizzi, Luigi (1997). The fine structure of the left periphery. In Elements of Grammar: Handbook in Generative Syntax, Liliane Haegeman (ed.), 281-337. Dordrecht: Kluwer.

Roberts, Craige (1998). Focus, the flow of information, and universal grammar. In The Limits of Syntax (= Syntax and semantics 29) Peter Culicover and Louise McNally (eds.), 109-160. New York: Academic Press.

Roberts, Ian (1991). Excorporation and minimality. Linguistic Inquiry 22: 209-218.

Ross, J. (1967). Constraints on variables in syntax. Ph.D. dissertation. MIT.

Samek-Lodovici, Vieri (1996) Structural contrastive focus in Italian, with and without emphatic stress. Ms. Rutgers University.

Selkirk, Elizabeth (1984). Phonology and Syntax. Cambridge, Mass.: MIT Press. 


\section{$78 \quad$ Kriszta Szendröi}

- (1986). On derived domains in sentence phonology. Phonology Yearbook 3: 371-405.

Szendrői, Kriszta (2001). Focus and the syntax-phonology interface. Ph.D. dissertation, University College London.

- (2002). Stress-focus correspondence in Italian. In Proceedings of Going Romance 2000, Claire Beyssade, Reineke Bok-Bennema, Frank Drijkoningen and Paola Monachesi (eds.), 287-303. Amsterdam/Philadelphia: John Benjamins.

Truckenbrodt, Hubert (1999). On the relation between syntactic phrases and phonological phrases. Linguistic Inquiry 30 (2): 219-255.

Tsimpli, Ianthi Maria (1995). Focussing in Modern Greek. In Discourse Configurational Languages, Katalin É.Kiss (ed.), 176-206. Oxford: Oxford University Press.

Tuller, Laurice. (1992). The syntax of postverbal focus constructions in Chadic. Natural Language and Linguistic Theory 10: 303-334.

Van Riemsdijk, Henk (1998). Categorial feature magnetism: The endocentricity and distribution of projections. Journal of Comparative Germanic Linguistics 2: 1-48.

Vilkuna, Maria (1995). Discourse configurationality in Finnish. In Discourse Configurational Languages, Katalin É.Kiss (ed.), 244-68. Oxford: Oxford University Press.

Vogel, Irene and Kenesei István (1987). The interface between phonology and other components of the grammar: The case of Hungarian. Phonology Yearbook 4: 243-263.

- (1990). Syntax and semantics in phonology. In The Phonology-Syntax Connection, Sharon Inkelas and Draga Zec (eds.), 339-363. Chicago: The University of Chicago Press.

Wexler, Kenneth and Peter Culicover (1980). Formal Principles of Language Acquisition. Cambridge, Mass.: MIT Press.

Williams, Edwin (1997). Blocking and anaphora. Linguistic Inquiry 28: 577-628.

- (2000). Representation theory. Ms. Princeton.

Zubizarreta, Maria Luisa (1998). Prosody, Focus, and Word Order. Cambridge, Mass.: MIT Press.

Zwart, Jan-Wouter (1997). Morphosyntax of Verb Movement. A Minimalist Approach to the Syntax of Dutch. Dordrecht: Kluwer.

Zwicky, Arnold (1969). Phonological constraints in syntactic descriptions. Papers in Linguistics 1: 411-453.

Zwicky, Arnold and Geoffrey Pullum (1986). The Principle of Phonology-Free Syntax: introductory remarks. In Interfaces (=Colombus Working Papers in Linguistics 32), Arnold Zwicky (ed.), 63-91. Colombus, Ohio: Ohio State University. 